\title{
Local Conflict in Indonesia Measuring Incidence and Identifying Patterns
}

\author{
Patrick Barron \\ Kai Kaiser \\ Menno Pradhan
}

\begin{abstract}
The widespread presence of local conflict characterizes many developing countries such as Indonesia. Outbreaks of violent conflict not only have direct costs for lives, livelihoods, and material property, but may also have the potential to escalate further. Recent studies on large-scale "headline" conflicts have tended to exclude the systematic consideration of local conflict, in large part due to the absence of representative data at low levels of geographic specification. This paper is a first attempt to correct for that. We evaluate a unique dataset compiled by the Indonesian government, the periodic Village Potential Statistics (PODES), which seeks to map conflict across all of Indonesia's 69,000 villages/neighborhoods. The data confirm that conflict is prevalent beyond well publicized "conflict regions," and that it can be observed across the archipelago. The data report largely violent conflict in 7.1 percent of Indonesia's lowest administrative tier (rural desa and urban kelurahan). Integrating examples from qualitative fieldwork, we assess issues in the measurement of local conflict for quantitative analysis, and adopt an empirical framework to examine potential associations with poverty, inequality, shocks, ethnic and religious diversity/inequality, and community-level associational and security arrangements. The quantitative analysis shows positive correlations between local conflict and unemployment, inequality, natural disasters, changes in sources of incomes, and clustering of ethnic groups within villages. The institutional variables indicate that the presence of places of worship is associated with less conflict, while the presence of religious groups and traditional culture (adat) institutions are associated with conflict. We conclude by suggesting future areas of research, notably on the role of group inequality and inference, and suggest ways to improve the measurement of conflict in the village census.
\end{abstract}

World Bank Policy Research Working Paper 3384, August 2004

The Policy Research Working Paper Series disseminates the findings of work in progress to encourage the exchange of ideas about development issues. An objective of the series is to get the findings out quickly, even if the presentations are less than fully polished. The papers carry the names of the authors and should be cited accordingly. The findings, interpretations, and conclusions expressed in this paper are entirely those of the authors. They do not necessarily represent the view of the World Bank, its Executive Directors, or the countries they represent. Policy Research Working Papers are available online at http://econ.worldbank.org.

\footnotetext{
* World Bank. The authors can be contacted at pbarron@worldbank.org, kkaiser@worldbank.org, and mpradhan@ worldbank.org. A version of the paper was presented at MOST UNESCO-LIPI (Indonesian Institute of Sciences) and UNDP Conference on Conflict in Asia-Pacific: State of the Field and the Search for Viable Solutions, 22nd-24th October 2003. The work was supported by DfID, AusAID and Dutch trust funds. Thanks to Juana C. Brachet, Scott Guggenheim, Bert Hofman, Ben Olken, Frances Stewart, Mohammed Zulfan Tadjoeddin, Jeremy Tobacman, , Bridget Welsh and Michael Woolcock, for their comments on drafts of this paper. Special thanks to Yulia Herawati and Kristen Stokes for excellent assistance. This version was presented at the Cornell Conference "75 Years of Development Research," May 7-9, 2004.
} 


\section{Introduction}

Headline conflicts such as major instances of civil war, and their ensuing set-backs for economic and political development, have in recent years been given increasing research attention (Collier 2002; World Bank 2003a). At the same time, pervasive and widespread local conflict characterizes many developing countries such as Indonesia, constituting both a barrier to development and, in some cases, providing the fuel for larger incidents of unrest. Realignments in power and resources, and challenges to existing interests and values, phenomena inherent in the development process, can lead to increased social tensions (Bates 2000). As such, major political and economic transition often finds states and their societies grappling with ways of preventing these smaller instances from escalating into more fully-fledged violent conflict.

Yet to date, systematic evidence on the presence of such local conflict, and on the potential underlying factors that might be associated with this incidence, has been limited. The extent of local violence in a country such as Indonesia (and variations in conflict incidence, type, and impact) suggests that intra-country empirical investigations offer an available starting point to a deeper understanding of conflict dynamics. This paper addresses issues relating to the measurement of conflict, and, using a unique census of villages commissioned by the Government of Indonesia (the Village Potential Statistics - PODES), investigates associated factors that appear to heighten the likelihood of violent local conflict.

Conflict is a feature of life for many in Indonesia. The fall of Soeharto's authoritarian New Order in 1998 was accompanied by a wave of violent unrest, which appears to be persistent. The old authoritarian regime managed conflict through repression with state structures regulated and vertical in nature (cf Tadjoeddin, et al. 2001a), and the army, through its presence in each 
and every Indonesian village, quelling any latent unrest. As Malley (2001) notes, the New Order used "coercive bureaucratic and military measures to prevent social tensions from developing into open, violent conflicts and to subdue them when they did."

High-profile conflict in East Timor, Central and West Kalimantan, Central Sulawesi, Papua, the Malukus, and Aceh have attracted international attention (Wilson 2001). However, there has been an increasing awareness that many regions of Indonesia are prone to destructive conflict (Barron and Madden 2003; Smith 2003; Welsh 2003). A recent government census of more than 69,000 villages and neighborhoods provides a unique opportunity to get a better understanding of the distribution of (violent) conflict across Indonesia, to investigate the empirical considerations related to tracking local conflict, and to test hypotheses relating to factors that may potentially be associated with local conflict. More than 7 percent of villages and neighborhoods in the census reported local conflict during 2002.

A growing international literature has sought to investigate conditions that affect the probability of countries experiencing large-scale violence and, in particular, the likelihood of civil war (cf Collier 2002; Humphreys 2003; World Bank 2003a). ${ }^{1}$ A range of arguments have been put forward as to the potential factors associated with such conflict. Economic arguments have focused on poverty, inequality, property rights, and the process of economic development and structure change. Social arguments have focused on the role of ethnicity and religion.

\footnotetext{
${ }^{1}$ The recent international literature has investigated those characteristics that make countries more prone to violence. The Correlates of War study at the University of Michigan and Pennsylvania State University (Singer 1990), and the Conflict Data Project at the University of Uppsala (Wallensteen and Sollenburgh 1998) have both compiled large cross-national datasets on wars and armed conflicts. Ted Gurr and Montey Marshall's work seeks to look at which state forms make civil war more or less likely (Gurr, et al. 2001).
} 
Political and institutional arguments have focused on community organization, including state versus communal security/policing arrangements.

Many developing countries are afflicted by high levels of communal and inter-communal conflict that does not take the form of civil war, but may yet be the source of significant destruction of livelihoods and material property. In Indonesia, for example, only Aceh would fall under Collier-Hoeffler's definition of civil war. ${ }^{2}$ The measurement of local conflict incidence for the purposes of more systematic evaluation of variance at low levels of geographic specification within countries has remained limited. Our contribution is meant as a starting point toward a better mapping and understanding of local conflicts within Indonesia, and aims to test some hypotheses about potential explanatory factors.

The paper proceeds in four sections. Section 2 sets out issues concerning the definition and empirical measurement of local conflict and lays out hypotheses about the factors associated with conflict. Section 3 describes quantitative and qualitative evidence on conflict in Indonesia. Section 4 estimates an empirical model to investigate which factors are associated with conflict based on the Indonesian village census. Section 5 concludes.

\section{Conceptual Framework}

Conflict is a complex phenomenon that takes on a very wide range of forms. Major instances of civil war entail significant casualties and can set development back by decades. At the other end of the spectrum, conflict is often a productive aspect of everyday interactions that

\footnotetext{
${ }^{2}$ The Collier-Hoeffler dataset focuses on civil war, defined as occurring when an identifiable rebel organization challenges the government militarily and the violence results in more than 1,000 combat related deaths, with at least 5 percent on each side (World Bank 2003a).
} 
does not escalate into violence. Within this spectrum falls a range of local conflicts that may persevere and/or escalate to major instances of violent conflict or even civil war.

\subsection{Defining and Measuring Local Conflict}

Measuring conflict incidence raises two fundamental issues: (a) the exact definition of conflict and the threshold at which an incident is defined as violent conflict within a given geographic jurisdiction; and (b) the conditions under which respondents might misreport or misperceive instances of conflict. Reporting biases relating to conflict are of special concern for statistical evaluations if these are themselves associated with some of the factors posited to be associated with conflict.

The Indonesia statistical agency (BPS) has adopted a definition of local conflict beyond some threshold of violence within a given locality in the past year, that may have been associated with loss of life, serious injury, or property damage. Localities are rural villages (desa) or their urban equivalents (kelurahan). Responses are compiled from village leaders and central government statistical agents (mantri statistik) posted at the sub-district level. This large-scale, quantitative collection of conflict data has its limitations. Given the challenges of capturing local conflict as a discreet incident, our paper explicitly integrates an in-depth qualitative conflict mapping exercise conducted in eight sub-districts (Barron, et al. 2004a), as well as comparisons with other quantitative data. We argue that the complexity of conflict, matched by its often widespread incidence, requires mixed quantitative-qualitative approaches (cf Rao and Woolcock 
2003). Prior to turning to this discussion, we outline the range of possible factors that might be associated with the likelihood of local conflict. ${ }^{3}$

\subsection{Potential Factors Affecting the Likelihood of Local Conflict}

The likelihood that conflict escalates into violence may be affected by economic factors including poverty, inequality, and income shocks/uncertainty; frictions between groups (e.g., across religious and ethnic group cleavages); and institutional factors (e.g., the extent to which violence is effectively mediated or, conversely, sanctioned by the state apparatus, including the police, and the legitimacy and effectiveness by which power/leadership is exercised in a community) (cf Humphreys 2003). The exact mechanisms by which these factors might affect the likelihood of conflict escalating beyond a certain threshold may be complex and highly context specific, as may be the exact pathways toward resolution, stalemate, and escalation (Barron, et al. 2004b).

Observers have emphasized different factors that may be associated conflict, and/or which are important to mediate tensions, in the Indonesian context. They include, but are not limited to, unemployment and inequitable development (Barron and Madden 2003), weak legal systems (Welsh 2003), the effect of industrialization (Miguel, et al. 2003), decentralization (ICG

\footnotetext{
${ }^{3}$ A growing literature has examined the incidence of crime and various associated economic factors at the international (cf Fajnzylber, et al. 2002) and at the local level (cf Demombynes and Ozler 2002). Crime and conflict are often strongly associated. For example, robberies may trigger conflict; incidents such as murder or rape may occur in the context of conflict. Some of the factors identified in the crime literature, including inequality, may also be associated with conflict, although often through different mechanisms. Whereas crime could be argued to be largely based around individuals (with varying degree of organization), instances of local conflict appear to be best defined in group/communal terms (Barron, et al. 2004b). The measurement of crime also faces issues of potential underreporting/reporting bias, although phenomena such as property or personal crime incidents can often be defined as more discreet events. While the Indonesian data from PODES also contains evidence of local crime (it asks whether stealing, robbery, plundering, torture/violence, arson, rape, use of narcotics and murder took place in a village in the past year, and whether levels increased, decreased, or remained the same) we consider an examination of this to be beyond the scope of this paper.
} 
2003), lack of clarity in land rights (Bennet 2002), regional economic disparities (Tadjoeddin, et al. 2001b), the mis-management of natural resources (ICG 2001; Ross 2002), and the capture of economic power by an ethnic group (Chua 2002).

Table 1 sets out hypotheses about potential factors associated with local conflict. Our hypotheses have been derived from the available international literature and on-going qualitative work (Barron, et al. 2004a). We briefly review these factors and suggest mechanisms by which these could be associated with conflict. Section 4 identifies quantitative proxies for each of these hypothesis measures at the village/neighbourhood, sub-district (kecamatan), and district (kabupaten/kota) level.

Table 1: Local Conflict Incidence Hypotheses

\begin{tabular}{|c|c|c|}
\hline Hypothesis Class & Hypothesis & Proxies \\
\hline \multirow[t]{5}{*}{ Economic } & Poverty increases conflict & $\begin{array}{l}\text { - Consumption based poverty measure defined at } \\
\text { district level (headcount/"depth") } \\
\text { - Relative Poverty of Village (BKKBN) as compared to } \\
\text { district average (defined using family planning lists) } \\
\text { - Village level share of unemployed }\end{array}$ \\
\hline & $\begin{array}{l}\text { Inequality among individuals increases } \\
\text { conflict }\end{array}$ & - Consumption based Gini coefficient in district \\
\hline & $\begin{array}{l}\text { Sudden loss of local income increases } \\
\text { conflict }\end{array}$ & $\begin{array}{l}\text { - Number of poor (according to family planning lists) } \\
\text { increased in the past year } \\
\text { - Natural disaster in the past three years }\end{array}$ \\
\hline & Economic development increases conflict & $\begin{array}{l}\text { - Does village have electricity? } \\
\text { - Share of families that work outside agriculture } \\
\text { - Are there residents who live outside of village for } \\
\text { work or school? } \\
\text { - Are there people who live in this village for work or } \\
\text { school who are not residents? } \\
\text { - Share of land that changed use in the past three year } \\
\text { (total, sawah, forestry) }\end{array}$ \\
\hline & Uncertain property rights increase conflict & $\begin{array}{l}\text { - Share of privately used agricultural land that is titled, } \\
\text { non-titled or community land } \\
\text { - Variables as above cross with land scarcity indicator } \\
\text { (hectare of agricultural land / population) } \\
\text { - Mining and/or forestry is main source of household } \\
\text { income }\end{array}$ \\
\hline \multirow[t]{2}{*}{ Social } & $\begin{array}{l}\text { Social diversity (ethnicity/religion) } \\
\text { increases conflict }\end{array}$ & $\begin{array}{l}\text { - Ethnic or religious diversity in a village } \\
\text { - Majority religious group in village differs within sub- } \\
\text { district } \\
\text { - Ethnic diversity in a sub-district or district } \\
\text { - Ethnic "clustering" across villages within sub-district } \\
\text { increases conflict }\end{array}$ \\
\hline & $\begin{array}{l}\text { What matters is really the types of diversity. } \\
\text { - inequalities between groups constitute a more } \\
\text { potent source of violent conflict than } \\
\text { inequalities among individuals (Stewart) }\end{array}$ & $\begin{array}{l}\text { - Number of religious institutions per household in } \\
\text { village } \\
\text { - Active faith group is present in the village } \\
\text { - Differences in educational endowment across major }\end{array}$ \\
\hline
\end{tabular}




\begin{tabular}{|l|l|l|}
\hline & $\begin{array}{l}\text { - What matters is how communal/ethnic } \\
\text { diversity is mediated through associational } \\
\text { forms on interaction across groups (Varshney) }\end{array}$ & $\begin{array}{l}\text { ethnic groups in a sub-district } \\
\text { - Inter-ethnic marriage exists in village } \\
\text { - Average Years of Schooling in District } \\
\text {-Presence of traditional/adat institutions }\end{array}$ \\
\hline Political/Institutional & $\begin{array}{l}\text { Lags/resistance in rural democratisation } \\
\text { increases conflict }\end{array}$ & -Villages without a new elected village council (BPD) \\
& $\begin{array}{l}\text { The absence of community watch } \\
\text { organization increases the likelihood of } \\
\text { conflict }\end{array}$ & -No community watch present \\
& $\begin{array}{l}\text { Absence of readily accessible police } \\
\text { presence increases the likelihood of conflict }\end{array}$ & $\begin{array}{l}\text {-Distance of nearest police post } \\
\text {-Nearest police post difficult to reach }\end{array}$ \\
\hline & $\begin{array}{l}\text { Leadership characteristics have an } \\
\text { influence on conflict }\end{array}$ & -Female village leadership decreases conflict \\
\hline
\end{tabular}

Economic deprivation or disparities in wealth may increase grievances. Economic shocks could lead individuals/groups of individuals to transgress on the property of others (e.g., through alleged livestock or petty theft), thereby serving as a trigger for further conflict escalation. Out-migration may denote lack of economic opportunity within a village, or indirectly lead to a decline in local social capital as individuals invest less in community associations as they expect their future to be elsewhere (Miguel, et al. 2003). Structural transformation away from (particularly subsistence) agriculture may increase uncertainty over incomes, and may necessitate new institutions (e.g., for property rights) as traditional/informal mechanisms are no longer able to cope with increasing land scarcity and new economic structures. Potentially, such transformations could also stretch traditional modes of communitylevel conflict resolution, either because these institutions are not geared to dealing with new situations, or because of growing tensions between formal and informal institutions. While formal land tenure may not necessarily denote security of tenure (World Bank 2003b), the absence of formal property rights for private agricultural land may make this a trigger for violent conflict, especially as land grows more scarce. Similarly, property rights over natural resource rents deriving from forests and mining are often ill-defined, and subject to high contestation, again precipitating conflict (or conflict escalation). 
The existence of various ethnic, religious, and/or linguistic groups could enhance the likelihood of conflict. The presence of multiple ethnic groups has often been associated with lower growth (Easterly and Levine 1997) and a higher probability of conflict or even civil war. Social sanctions against shirking may also be more difficult across ethnic groups, hence weakening cooperative outcomes (Miguel and Gugerty 2002). Different groups may operate under different rule frameworks that allow for the peaceful resolution of conflict; when these competing rule systems come into contact, conflict escalation can be the result (Barron, et al. 2004b). Collier (2001) suggests that the impact of group diversity depends on the type of diversity; for example a certain degree of dominance on the part of an ethnic group could see it exploit a minority rather than stimulate "encompassing" policies that benefit all groups in a jurisdiction. Similar mechanisms could also be associated with conflict at the local level. At the international level, he finds some weak evidence of the impact of a particular range of dominance (namely a single group with $45-60$ percent of the population share) on growth outcomes. Local conflict in Indonesia is often triggered across jurisdictions. Consequently measures of group "clustering" (or to use a more normative term, segregation) may be associated with conflict.

Stewart (2000) has argued that horizontal inequalities - differences between groups in political opportunities, economic assets, employment and incomes, and social access and situations - play an important role in determining when and where violent conflict will take place.

Ashutosh Varshney's (2002) work on India has argued that fragmented social infrastructures, where participation in associational structures and informal networks consolidates identities and interests along, rather than across, religious and ethnic lines, explains 
variation in violence and peace in otherwise similar areas. He argues that especially in urban areas, day-to-day interactions are insufficient to provide a bridge across ethnic/religious groups that stops conflicts from escalating into communal violence. Communal violence therefore proves less likely in cities where associations can act as bridges across groups.

Local institutions and leadership could provide the mechanisms for reducing or mediating conflict in line with Varshney's hypothesis. On the other hand, these same institutions may also be instrumental in mobilizing individuals to engage in conflict, increasing the capability for collective action to defend group interests. In the analysis we distinguish between political institutions, religious institutions, and informal religious and adat (traditional customs) groups. The introduction of the democratic village council (BPD) is a centrally mandated institutional change aimed at increasing accountability of village leaders. Eighty percent of the villages had instituted a BPD by the time of the PODES fielding. The absence of a BPD may reflect delays in the implementation of this regulation, and/or entrenched opposition by local elites to these democratization measures or even pre-existing conflict. Female leadership may affect the ability to avert violent conflict. The presence of women in leadership positions may be indicative of a community's openness to broader participation of typically excluded groups.

The presence of different forms of group organization may ameliorate as much as escalate violent conflict. Depending on context, the form of group organization - and associated measures to distinguish among these - as much as the levels of group diversity may require further investigation. More formal religious institutions that organize a larger number of people may have a greater capacity and longer run interest in avoiding violent conflict than informal groups. In contrast, informal organizations that are neither mandated by the state nor part of formal religious organization may be more successful in solving community problems 
(Wetterberg 2002). At the same time, customary adat (customary law) institutions might be indicative of an increased adherence to traditional laws and customs. As such, they may also clash with centrally mandated conflict resolution mechanisms, providing the potential for conflict escalation.

Inadequate policing, ineffective courts and judicial system that allow for high levels of crime tend to also create space for violent conflicts to take place; incidents of crime, when severe, may also constitute conflicts in themselves. ${ }^{4}$ Public and communal security arrangements may therefore reduce the likelihood of conflict. However, their existence may also be in response to a worsening security situation.

\section{Empirical Evidence on Local Conflict}

The Government of Indonesia's Village Potential Statistics survey (PODES) offers perhaps the first opportunity to look at the incidence and causes of conflict across Indonesia on a nationwide scale. This section summarizes conflict incidence based on the data from PODES, and examines reporting issues. Our comparison to a detailed qualitative study of local conflict (Barron, et al. 2004b) suggests that key-respondent (i.e., village heads) based approaches like the PODES are subject to reporting problems. Treated as a complement to more in-depth studies, however, they provide an opportunity to map levels of conflict and to test some of the

\footnotetext{
${ }^{4}$ Qualitative fieldwork in over two dozen villages (see Section 3) provided some insight into the linkages between conflict and crime, as well as the underreporting of crime. In three districts studied, the Bank study followed conflicts which involved rape as a trigger. In these cases, rapes were public knowledge; indeed, it was the fact that the act had been brought to public attention - rare, given the norm of treating such matters as a family concern, and keeping it within the household as a result - that had led to the triggering of a broader social conflict. Likewise, whereas none of the thirteen villages in East Java reported having experienced arson in the previous year, conflicts in a number of these villages had resulted in the burning of property (privately- and publicly-owned).
} 
competing claims about the factors associated with high levels of conflict. ${ }^{5}$ Other intermediate approaches to surveys or local fieldwork for the systematic mapping of violence and conflict include the use of national and, increasingly, local media sources (Tadjoeddin 2002; Welsh 2003). ${ }^{6}$

\subsection{The PODES Data}

The Central Bureau of Statistics' (BPS) Village Potential series (PODES) is a longstanding tradition of collecting data at the lowest administrative tier of local government. It collects detailed information on a range of characteristics - ranging from infrastructure to village finance - for Indonesia's current 69,000 villages and neighborhoods. ${ }^{7}$ The latest PODES was surveyed at the end of 2002 as part of the 2003 Agricultural Census.

\footnotetext{
${ }^{5}$ Other sources of information on conflict include the police, health care providers, morgues, and the Indonesian army (TNI). However, it is very difficult to use these data sources for cross-provincial comparisons, in part because of large gaps in the data but also because common definitions (for example of violence types) are not used in different areas.

${ }^{6}$ In the absence of any primary data, the United Nations Support Facility for Indonesian Recovery (UNSFIR) attempted to create such a dataset by compiling newspaper reports on violent conflicts (Tadjoeddin 2002). However, in large part because of the use of national media, which often do not record localized conflicts, the resulting data massively underreports levels of conflict. The UNSFIR dataset captured only 1,093 incidents of conflict over an eleven-year period (1990-2001). In contrast, PODES documented almost 5,000 villages as reporting conflicts in 2002 alone. Newspaper reports will also be subject to biases. For example, newspapers may only report high profile violent conflict. At the same time, coverage may differ significantly across regions. Areas with high readership or local correspondent penetration may also yield regional over-reporting biases. The PODES for example suggests that local newspapers are only available in 55.9 percent of villages. While readership may not be a proxy of correspondent coverage, clearly urban areas may be subject to more intense scrutiny. However, in large part because of the use of national media, which often do not record localized conflicts, the resulting data massively underreports levels of conflict. While further work is being conducted by UNSFIR, UNDP, the World Bank and independent researchers using local media sources, which appear to more accurately report conflict, the creation of a national dataset by such means is still a long way away.

${ }^{7}$ The module was apparently initiated by the BPS Directorate of National Resilience (Ketahanan) under Drs. Suharno. The PODES is typically conducted in conjunction with the Population Census (e.g., 1990 and 2000), the Economic Census (1986 and 1996), and the Agricultural Census (1993 and 2003) (Kaiser and Molyneaux 2000).
} 
The 2003 PODES for the first time included a section on politics, conflict and crime (see Annex 2). Sub-district level statistical agents (mantri statistik), who work for BPS, implement the survey. Information is typically derived from the kepala desa (village heads) and lurah (neighborhood heads) about the occurrence of conflict in the previous year. If conflict was reported, the survey asked for the type of conflict, whether it was longstanding, and the impacts of the conflict (fatalities, injuries, and material damage). Finally, the survey also asked if the conflict was resolved, and if so, by whom (citizens, village apparatus, or security apparatus).

\section{Levels and Types of Conflict}

Just over 7 percent of villages and neighborhoods reported local conflict during the previous year (a total of 4,872 incidents) (Table 2). The incidence of local conflict is higher in urban areas ( 8.8 versus 6.7 percent). The relative incidence of conflicts appears to be somewhat higher off-Java than on Java. However, this difference is largely explained by the high incidence of conflict in Aceh (23.4 percent of jurisdictions). Omitting Aceh, the reported rates of conflict incidence for Java and off-Java are more similar (5.4 versus 5.7 percent). Figure 1 reports conflict incidence at the district (kabupaten and kota) level, mapping the share of communities in each district reporting conflict. The map highlights that conflict incidence is spread throughout the archipelago.

Almost a quarter of reported conflicts were alleged to have involved fatalities, about half injuries, and about a third material damage. Total fatalities arising from conflict were reported to be 4,869. Reported injuries amounted to 9,823 injuries and material damages of 771 billion rupiah (est. 91.4 million USD).

The majority of conflicts on Java (72 percent) were reported to be new. At first blush, less than half of all conflicts off-Java (3.9 versus 8.0 percent incidence) were new. However, the 
rate is almost identical to that on Java if Aceh is excluded, reflecting the continuous nature of reported conflict in that province.

Table 2: Local Conflict

\begin{tabular}{|l|c|c|l|c|}
\hline & $\begin{array}{l}\text { Conflict } \\
\text { Reported (\%) }\end{array}$ & $\begin{array}{l}\text { Violent } \\
\text { Conflict } \\
\text { Reported } \\
(\%)\end{array}$ & $\begin{array}{l}\text { New } \\
\text { Conflict } \\
(\%)\end{array}$ & $\begin{array}{l}\text { Total } \\
\text { Villages/Neighborhoods }\end{array}$ \\
\hline National & 7.1 & 4.4 & 3.9 & 68,815 \\
\hline Rural & 6.7 & 4.2 & 3.6 & 56,748 \\
\hline Urban & 8.8 & 5.8 & 5.7 & 12,067 \\
\hline Java & 5.4 & 3.6 & 4.0 & 24,962 \\
\hline Off-Java & 8.0 & 4.9 & 3.9 & 43,853 \\
\hline Off-Java (ex. Aceh) & 5.7 & 3.5 & 4.1 & 38,118 \\
\hline \multicolumn{2}{|l}{ Source: PODES 2003 (Questions 17.03) } \\
\hline
\end{tabular}

The highest rates of villages and neighborhoods reporting conflict by province were in Aceh (23.4 percent), Maluku (15.7 percent), and NTB (13.8 percent) (see Table 3). The lowest incidence of conflict was reported in South Kalimantan (1.4 percent), South Sumatra (2.3 percent), and Bengkulu (2.4 percent) (see Table 3 ).

Table 4: Type of Local Conflict

\begin{tabular}{|l|c|l|l|l|l|l|c|}
\hline & $\begin{array}{l}\text { National } \\
(\%)\end{array}$ & $\begin{array}{l}(\% \text { of } \\
\text { which } \\
\text { violent })\end{array}$ & $\begin{array}{l}\text { Rural } \\
(\%)\end{array}$ & $\begin{array}{l}\text { Java } \\
(\%)\end{array}$ & $\begin{array}{l}\text { Off-Java } \\
(\%)\end{array}$ & $\begin{array}{l}\text { Off-Java, } \\
\text { non-Aceh } \\
(\%)\end{array}$ & $\begin{array}{l}\text { Aceh } \\
(\%)\end{array}$ \\
\hline Civil/Group Strife & 52.1 & 64.6 & 48.5 & 76.2 & 42.9 & 67.1 & 3.6 \\
\hline Strife w/ Gov Apparatus & 7.0 & 66.5 & 7.6 & 3.6 & 8.4 & 5.4 & 13.2 \\
\hline School Strife & 2.7 & 45.9 & 1.8 & 3.9 & 2.2 & 2.8 & 1.2 \\
\hline Ethnic Strife & 3.3 & 51.8 & 3.2 & 1.0 & 4.2 & 6.5 & 0.5 \\
\hline Other & 34.9 & 58.4 & 38.9 & 15.3 & 42.4 & 18.2 & 81.4 \\
\hline$(N)$ & 4,958 & 61.7 & 3,875 & 1,376 & 3,582 & 2,213 & 1,369 \\
\hline Source: PODES 2003 (Questions 17.04a)
\end{tabular}


Table 4 lists the reported type of conflict. Just over half of conflicts were categorized as civil strife. The ratio was almost three-quarters on Java. Ethnic strife accounted for only 3.3 percent of reported conflict incidents. Ethnic conflict was more important off-Java. Omitting Aceh, ethnic conflict accounted for 6.5 percent of conflict incidents off-Java (but only 1 percent on Java). Within conflict types, the majority of instances were reported as violent, except in the case of school strife (student clashes).

\section{The resolution of conflict}

Almost three-quarters (72 percent) of conflicts were reported to have been resolved. The security apparatus was most frequently mentioned as the agency that ended the conflict (45.7 percent). This ratio tended to be higher on Java.

Table 5: Agency in Conflict Resolution

\begin{tabular}{|l|l|l|l|l|c|c|}
\hline & $\begin{array}{l}\text { National } \\
(\%)\end{array}$ & $\begin{array}{l}\text { Rural } \\
(\%)\end{array}$ & $\begin{array}{l}\text { Java } \\
(\%)\end{array}$ & $\begin{array}{l}\text { Off- } \\
\text { Java } \\
(\%)\end{array}$ & $\begin{array}{l}\text { Off-Java, } \\
\text { non-Aceh } \\
(\%)\end{array}$ & Aceh \\
\hline Population & 21.0 & 23.0 & 13.1 & 25.5 & 15.0 & 74.9 \\
\hline Village Apparatus & 33.2 & 34.6 & 34.7 & 32.4 & 37.4 & 9.0 \\
\hline Security Apparatus & 45.7 & 42.4 & 52.2 & 42.1 & 47.7 & 16.0 \\
\hline (N) & 3,544 & 2,605 & 1,269 & 2,275 & 1,876 & 399 \\
\hline \multicolumn{7}{|l|}{ Source: PODES 2003 (Questions 17.04e) } \\
\hline
\end{tabular}

Village institutions were attributed with ending conflict in a third of the cases, and were relatively more important off-Java. Aceh stands in marked contrast to all other provinces. Not only were the vast majority of conflicts classified as "other", but the comparative rates at which village or security apparatuses were credited with resolving conflicts was only about one-third (compared with more than three-quarters in the rest of the archipelago). 


\subsection{Field Verification of PODES Conflict Reporting}

As part of a study on conflict and community-driven development being undertaken by the World Bank (Barron, et al. 2004a), a team of researchers conducted an intensive mapping and evaluation exercise in four districts (kabupaten) in East Java and NTT. The provinces were chosen to be different using both formal (PODES, SUSENAS) and informal (interviewing at the national and provincial levels) sources. Two districts were then purposively selected within each province as having either a high capacity to manage conflict (Ponorogo in East Java; Sikka in NTT) or a low capacity (Pamekasan in East Java; Manggarai in NTT). Within each district two 'matching' sub-districts (kecamatan) were picked based on program evaluation considerations. ${ }^{8}$

After a conflict mapping exercise at the district and sub-district levels, 25 'case' villages were chosen purposively within the selected sub-districts on the basis of a number of criteria aimed at targeting the most interesting conflicts to track. Findings from this work provide some valuable insights into the reporting of conflict incidence from PODES, in particular definitions, categorizations, and incentives for reporting on the part of key respondents such as village heads. The qualitative fieldwork obtained detailed information on 25 and the conflicts within each. We cross-checked the groups of questions from PODES that considered conflict, its impacts and the way it is resolved (PODES questions $1703-1704$ ).

\footnotetext{
${ }^{8}$ The KDP \& Community Conflict Negotiation study is a large-scale mixed methods study of local level conflict and conflict resolution in Indonesia which aims to ascertain - systematically and empirically - the factors that affect local level conflict management capacity and that contribute to varying levels of violent conflict (Barron, et al. 2004a). In addition to identifying the factors that impact on local capacity to manage conflict, the research also examines the extent to which the Kecamatan Development Program (KDP), the Bank's primary community development program in Indonesia, impacts on communities' conflict management ability. Because the research is evaluating program impact, in each district a treatment (KDP) sub-district and control (non-KDP) sub-district were selected. These sub-districts were matched, using propensity scoring techniques and qualitative verification.
} 


\subsection{Levels and Impacts of Conflict}

Comparing the two data sources hints at significant underreporting of conflict in PODES (see Table 6). Of the 25 villages, PODES reported only four as having experienced conflict in the previous year: one out of 13 in East Java (7.7\%), and three out of 12 in NTT (25\%). While we would not have expected all of the villages to have registered as having conflict in the PODES - because not all of the conflicts we tracked took place in the year 2002 - this does suggest that PODES is not capturing all conflicts.

Table 6: Comparison of Data Sources - Local Conflict Mapping

\begin{tabular}{|c|c|c|c|c|}
\hline $\begin{array}{l}\text { District } \\
\text { (\% desa/kelurahan } \\
\text { reporting conflict } \\
\text { PODES) }\end{array}$ & $\begin{array}{l}\text { Overall \# } \\
\text { desal } \\
\text { kelurahan } \\
\text { (kecamatan) }\end{array}$ & $\begin{array}{l}\text { Desa } \\
\text { (kecamatan) } \\
\text { studied } \\
\text { in field } \\
\text { research }\end{array}$ & $\begin{array}{l}\text { \# (\%) selected } \\
\text { desa } \\
\text { Reporting } \\
\text { Conflict } \\
\text { (PODES) }\end{array}$ & $\begin{array}{l}\text { \# (\%) selected } \\
\text { desa } \\
\text { with Conflict } \\
\text { (based on Fielc } \\
\text { Assessment) }\end{array}$ \\
\hline \multicolumn{5}{|l|}{ East Java (3.5\%) } \\
\hline Ponorogo (1.7\%) & $303(21)$ & $6(2)$ & $1(16.7 \%)$ & $6(100 \%)$ \\
\hline Pamekasan (3.2\%) & $189(13)$ & $7(2)$ & $0(0 \%)$ & $6(85.7 \%)$ \\
\hline \multicolumn{5}{|l|}{ NTT (11.6\%) } \\
\hline Sikka $(14.3 \%)$ & $140(8)$ & $6(2)$ & $2(33.3 \%)$ & $3(50 \%)$ \\
\hline Manggarai (12.0\%) & $375(16)$ & $6(2)$ & $1(16.7 \%)$ & $6(100 \%)$ \\
\hline
\end{tabular}

The case of Pamekasan, a district on the island on Madura, just off the Javanese coast near Surabaya, provides a stark example. None of the seven villages studied in Madura were reported in PODES as having experienced conflict in the past year. Yet, in six of the seven villages, the World Bank researchers tracked conflicts that had taken place in $2002,{ }^{9}$ including mass sickle battles between communities and the burning of alleged dukun santet (witch doctors). Similarly, in Ponorogo, close to Central Java, PODES reported only one village as

\footnotetext{
${ }^{9}$ In the other village, the conflict followed had taken place previous to 2002 and the researchers determined that no significant conflict had taken place in 2002.
} 
having experienced conflict in the past year; researchers followed conflicts that had taken place in 2002 in all six villages chosen from that district. Conflicts here included battles between rival silat (martial arts) groups, clashes over village head elections, and a dispute between a community and a state-run mining enterprise.

There appeared to be a similar trend of underreporting in the NTT districts. In Manggarai, the westernmost district on the island of Flores, only one of six villages reported conflict; yet, according to the research teams on the ground, all six had experienced significant unrest in the previous calendar year. Whereas PODES did pick up conflict over land between groups in Tanah Rata village, it missed a range of other land conflicts across the district. In Sikka, the figures from PODES and the field research were closer: PODES reported two villages as having experienced conflict; the qualitative assessment determined that three villages had been the location for conflict in the previous year.

The impacts of conflict were also underreported in the PODES. Across the 25 villages, PODES reported three injuries and no deaths as resulting from conflict. Analysis of the qualitative primary data from the research sites, as well as secondary sources including figures from the police, health care providers and newspaper sources, would indicate that the human costs of violent conflict in the villages studied were in fact much higher. Likewise, a large percentage of the cases followed in the qualitative research involved property (private, company or state-owned) being burnt down; these financial costs were, by and large, not picked up by PODES.

\subsection{Insights from Comparison of PODES and Qualitative Data Sources}

The comparison of the broad PODES data with that gathered in the more in-depth qualitative work hints at some of the weaknesses in the PODES dataset. There appears to be a 
significant underreporting of conflict. PODES did not pick up many of the conflicts observed in the villages where the in-depth research was conducted.

It should not be surprising that in-depth qualitative evaluations would yield more instances of local conflict. A better understanding of why conflict is underreported provides some insights for improvements for future survey design (e.g., in the context of the 2005 PODES), but also whether under-reporting is systemic or whether it varies across area. If errors in reporting levels are correlated systematically with particular features of these localities, this introduces bias in a regression framework.

There are at least two reasons why conflict might be under-reported in PODES. The first concerns cognition: how respondents understand the questions asked. The PODES instrument asks whether a village has experienced conflict in the past year, but it does not say what is meant by conflict. Does conflict only include large-scale incidents with large numbers of deaths or material destruction? Is violent crime a kind of conflict? In many places village head elections result in the polarization of villages into two hostile groups. If violence appears to be latent, but has not yet erupted, should this be counted as being an example of conflict?

Preliminary evidence from PODES suggests that village heads tend to define conflict narrowly, only reporting conflict as having occurred if it was violent and had significant human or physical impacts. In $62.7 \%$ of villages reporting conflict, respondents explicitly identified deaths, injuries or material damage.

A second explanation for the lower levels of conflicts in PODES is functional and relates to the incentives, or lack thereof, for village heads to give an accurate and honest response to questions about conflict in their village. In the absence of clear knowledge about the purposes of the survey - and how the resulting data will be used - village heads may understate problems in 
their village. ${ }^{10}$ Experience from qualitative fieldwork would suggest that this problem is a real one. In many cases, authority figures would fail to mention significant conflicts that were only later discovered after the number and type of informants was increased. Further, lack of disclosure may have a moral as well as rational basis. Conflict, in Indonesia as elsewhere, is often seen as a sign of failure, with harmony in village life particularly valued. ${ }^{11}$ As such, it is not surprising that many village heads might be economical with the truth when describing unrest in their villages. ${ }^{12}$

What are the implications for how we interpret PODES and to what extent does it limit the dataset's utility in mapping conflict and assessing its causes? The first clear implication is that levels of conflict may in fact be significantly higher than the PODES data would suggest. This conclusion is backed up by other case study research - using qualitative and secondary data

\footnotetext{
${ }^{10}$ Under the New Order, the village head was appointed by, and accountable to, the district government. While this fundamentally changed under the regional autonomy law (Law 22/1999), with village heads elected and accountable to the elected village council (BPD), in reality changes have been slow coming, with the new system only recently implemented in some districts, and still awaited in others (Antlov 2001).

${ }^{11}$ Many anthropologists of Indonesian life stress the value local communities place upon harmony and social cohesion. See, for example, Tule (2000) who emphasises the importance in Flores of the 'house' as a provider of harmony: "for the Keo of Flores and other tribes in NTT [the house] is a cultural force which plays a centripetal role in uniting and incorporating its members into a social unit ... [a] system has been built up which supports the harmonious relationship among house members, both Christians and Muslims." While the extent to which such harmony actually exists in Flores, or elsewhere in Indonesia, is a subject for hot debate, the degree to which the discourse frames discussion of social relations in many villages is incontestable.

${ }^{12}$ Comparing the PODES data with the results of the qualitative research reveals that there is less of a difference between the two data sources on less sensitive issues. For example, the data on the characteristics of village leadership broadly matched that derived from the qualitative fieldwork. Aside from some discrepancies in the age and education of the village head (they tended to report themselves as younger and more educated than they actually were!) the two data sources generally verified each other.
} 
- that would indicate that in at least some parts of Indonesia, levels of violent conflict are higher than those reported in PODES. ${ }^{13}$

While the figures do not report all conflicts in Indonesia, as long as this underreporting is systemic (that is, fairly equal across regions or characteristics of regions) the data still provide information about relative levels of conflict across regions (e.g., which provinces have higher levels of conflict) thus allowing for consideration of potential factors associated with conflict. If the same questions were asked again in the next PODES (2005/6) it would also tell us whether conflict levels were increasing or decreasing, both nationally and for a given area.

The comparison with qualitative work to-date suggests that while PODES may not accurately represent true levels of conflict across Indonesia, there is little evidence to suggest that the data are biased by particular characteristics of different localities. Under-reporting in East Java and NTT research sites were of similar magnitudes across areas with different majority religions, at different stages of development, and with different levels of conflict. Consistent ratios of conflict relative to conflict with explicit casualties and material damage also suggest at least some common understanding of conflict across cultures. The five provinces with a ratio of reported conflict to explicitly violent conflict (involving deaths/injuries/material damage) of 50 percent or less were spread across three very different islands (Kalimantan, Sulawesi, and Java). A focus of future quantitative work will have to be improved survey design and respondent selection methods to elicit actual levels of bias, as well as to control for different cultural understandings of what defines particular conflict thresholds.

\footnotetext{
${ }^{13}$ For example, Welsh's (2003) study of vigilante killings in West Java and Barron and Madden's (2003) study of Lampung would suggest levels of conflict higher than the respective PODES provincial rates of $7.9 \%$ and $3.5 \%$.
} 


\section{Empirical Results}

This section tests which regionally specific factors correlate with conflict as it is reported in the 2003 PODES data. We use the analytical framework as a basis for the selection of variables to be included in the model. The estimated coefficients should be viewed as measures of association, rather than causation. Almost any variable could be considered endogenous in the model as conflict affects almost all aspects of civic, political and economic life. In addition, respondent bias could cause apparent correlations between variables reporting conflict and right hand side variables drawn from the same data source.

We derived proxies for local poverty, inequality, diversity, economic shocks, land tenure, and community political, associational, and security arrangements from the PODES, 2000 Population Census and the 2000 SUSENAS household survey (see Table 7). In the case of the PODES, we were able to utilize these variables at the local level. We matched variables from the Population Census as the sub-district level. SUSENAS data on household consumptionrelated indicators were available at the district level.

A logit model is applied and estimated at the village level. Table 8 reports estimated coefficients of the models with the variable indicating whether the community experienced conflict in the past year the dependent variable. ${ }^{14}$ In our estimates we distinguish between rural and urban areas, based on the assumption that conflict dynamics may be structurally different

\footnotetext{
${ }^{14}$ The model controls for the fact that observations might not necessarily be independent within sub-districts. Our variable was define as one whether or not the community reported casualties or material damage. The results for the narrower definition of conflict were very similar.
} 
between the two. ${ }^{15}$ We present estimates including and excluding provincial dummies, and with or without Aceh. A range of factors, including propensity to report, may vary at the provincial level.

Hypothesis: Poverty is associated with increased conflict. Our estimates focused on both absolute consumption poverty levels at the district level (from the SUSENAS), how poor a locality was relative to its respective district (PODES), and recent trends in locality poverty. ${ }^{16}$ District poverty levels appeared to increase the likelihood of conflict (Table 8, (3) \& (4)), although this was no longer the case when provincial dummies were added for the provinces (Eq., 1-2) or when we added Aceh to the sample. This suggests the province specific dynamics of district poverty incidence may matter. In one of our qualitative case study provinces, East Java, poorer districts actually seemed to be associated with less conflict (Eq. 7). Although relative poverty did not appear to be significantly associated with conflict, changes in poverty were significant in rural areas.

Hypothesis: Inequality is associated with increased conflict. Although the SUSENAS allows us to calculate a measure of household consumption inequality, the indicator is only

\footnotetext{
${ }^{15}$ The qualitative work in the previous section focused on rural areas (desa) in East Java and NTT. In contrast, for example, the work of Varshney on communal conflict in India focuses on cities.

${ }^{16}$ We created the Poverty Gap index of poverty (Foster Greer Thorbecke) using per capita consumption as a welfare measure. The poverty gap is based on the average distance that the poor's consumption falls below the poverty line. We defined village-based poverty from the PODES, based on the Indonesian family planning board's (BKKBN) census of poor households. The indicators are whether a household has an earth floor, whether household members have separate clothing for work and leisure, whether they are able to perform their religious duties, and if households are able to seek medical care when needed. Relative poverty is defined as $p_{i j}^{r e l}=p_{i j} / \bar{p}_{j}$ where $p_{i j}$ the fraction of poor households in village $i$ in region j. $\bar{p}_{j}$ is the mean poverty rate in all villages in district $\mathrm{j}$. Our relative measure was based on a question which asked whether there had been a recent increase in these "poverty letters."
} 
available at the district level. This district level indicator may reflect urban-rural disparities in a district, rather than individual disparities. We therefore constructed an indicator based on educational attainment disparities from the Census, for males aged 20-30. The measure encompasses not only differences in access to education for a comparable age group, but also is indicative of income inequality as earnings are highly correlated with education. We find that in rural areas, higher inequality in this measure is associated with higher conflict, a result we also find when applying the provincial dummies.

\section{Hypothesis: Unemployment and current lack of economic opportunity is associated}

with increased conflict. Localities with higher unemployment shares (based on the PODES) were associated with higher conflict. This finding is not surprising, as especially among young men it can be a factor underlying conflict situations (Barron and Madden 2003).

Logit coefficient variables are difficult to interpret directly. Unlike standard OLS estimates, the marginal impact of a variable cannot be directly read off the coefficient, but depends on the relative value of all other values (Long and Freese 2003). Unemployment was reported as 4 percent in the average locality. Although this measure certainly masks a high degree of underemployment, it serves as a general measure of economic conditions or shocks in a village. The estimate of the marginal effect indicates that a 10 percent point increase in unemployment is associated with a 0.6 percent point (or 10 percent based on an average probably of 6-7 percent) increase in the likelihood of conflict.

Hypothesis: Shocks increase the likelihood of conflict. A recent natural disaster in a locality was positively associated with conflict across the range of specifications. A natural disaster in the community increases the likelihood of conflict by 1.7 percent point (evaluated for all other variables at their mean in equation 1). The probability of conflict in rural areas 
(excluding Aceh) is 6 percent. This suggests that a natural disaster increases the likelihood of conflict by 29 percent.

\section{Hypothesis: Insecure income sources are associated with increased conflict. Changes}

in the structure of the economy create insecurity over future income streams. When agriculture does not provide sufficient income, households need to move to other sectors, or outside of the village. Inward migration increases the competition for sources of income, and may in this way increase conflict. For instance, tensions heightened in districts in Madura after the inflow of internally displaced people (IDPs) from Kalimantan. We hypothesize that this insecurity in income sources leads to higher levels of social tensions, and thus higher levels of conflict.

The share of individuals working outside of agriculture did not show any association with conflict in either rural or urban areas. The presence of inward or outward migration was positively associated with conflict in rural areas, although we did not find a similar effect in urban areas. In urban areas, almost every community reported in- and outward migration (90 and 98 percent respectively), and even in rural areas these figures were high (67 and 96 percent respectively). Ideally future work will yield measures of the intensity of migration impacts, and the conditions under which these seem to be associated with higher incidences of conflict.

We constructed a measure of structural change based on the share of agricultural land that was converted to other purposes in the past year (estimated to be about 3 and 2 percent respectively in the average urban neighborhoods or rural villages). This indicates that land conversions were positively associated with conflict in rural areas. The result also showed up significantly in NTT.

Hypothesis: Insecurity of property rights is associated with increased conflict. The PODES defines three categories for agricultural land: privately-used land with title, privately- 
used land without title, and communally-used land (including that for village heads). ${ }^{17} \mathrm{We}$ examined whether lack of titling in private land was associated with heightened conflict, and found very mixed results. In most specifications the results were insignificant. In urban areas in the absence of provincial dummies the variable was actually associated with lower conflict. Rural results for NTT seemed to be more in line with expectations, but were not significant at the 5 percent level. The results underscore that formal title does not necessarily denote security of tenure, the absence of which could fuel conflict (World Bank 2003b).

We also constructed indicators from the PODES that are set to one if mining or forestry are the mains sources of household income. For both of these sectors, property rights are ill defined. We did not find any significant effects of these variables on conflict, except in the case of East Java, where villages that depended primarily on mining were associated with higher levels of conflict.

Hypothesis: Group diversity is associated with increased conflict. The 2000 Population Census collects self-reported ethnic status, a first for Indonesian household questionnaires since before the start of the New Order. Over 1000 different ethnic groups were reported. We use the responses to these answers to construct a sub-district level indicator of ethnic diversity. We were unable to develop village level measures because of the difficulty of matching the Census and the PODES at the village level. The PODES provided a limited number of diversity measures at the local level, including the presence of multiple ethnic groups, whether there were different

\footnotetext{
${ }^{17}$ Since only three quarters of villages provided a detailed decomposition of land use, we introduced a dummy to denote reporting and set the remaining values of this variable to zero.
} 
main religions across localities within a sub-district, and whether there were marriages across ethnic groups in a village.

We constructed various regional measures of ethnic and religious fractionalization, as well as clustering/segregation within regions (see Annex 1). Fractionalization refers to the probability that individuals within a region are from a different group, whereas clustering suggests that this diversity is concentrated in certain areas within a region. ${ }^{18}$ Problems can easily be framed in an 'us versus them' way if villages are dominated by one ethnic group. ${ }^{19}$ Collier (2001) suggests that dominance - rather than high diversity or homogeneity - on the part of one group (e.g., 45 to 90 percent) may be associated with conflict, for example as this group raises grievances in order to attempt to monopolize local resources. Finally, we also generated measures of horizontal group inequality (Stewart 2002), to capture whether different groups have very different educational endowments. ${ }^{20}$

There was some evidence that diversity was associated with higher conflict, although the results are very tentative. The presence of more than one religion in a sub-district increased the likelihood of conflict in a sub-district in both urban and rural areas, although this result washes out with the addition of provincial dummies. Our Theil measure of ethnic diversity did not yield significant results, except in NTT where it was associated with higher conflict. Our village level measure of ethnic diversity did not yield significant associations. Clustering of ethnic groups

\footnotetext{
${ }^{18}$ In contrast to fractionalization, polarization occurs when there are two groups of equal size (Alesina, et al. 2003).

${ }^{19}$ The reverse causality is also plausible. If conflict between ethnic groups arises, individuals within groups may migrate and look for protection by living close to others from the same group.

${ }^{20}$ Our definition calculates the ratio of the highest average household head education within a group to the lowest in a district. To avoid small group effects, we dropped all groups that were reported to be less than five percent of the population share in a district.
} 
across villages was associated with higher levels of conflict in rural areas. There was some evidence that lack of dominance or high fragmentation, defined as no single group having more that 40 percent of a sub-district's education share, was associated with higher conflict. The presence of inter-ethnic marriages in rural areas was associated with higher conflict. Counter to prediction, our measure of horizontal inequality (see Annex 1) seemed to be associated with lower levels of conflict in rural areas. Further research is needed to scrutinize, and help us understand, this result. More effort needs to be devoted to constructing indicators of horizontal inequality at lower levels of geographic disaggregation. Our measure, which focuses on the best versus the least endowed group, could be contrasted with one that focuses on more intermediate ranges. Further work could focus on which group differences matter in fueling conflict, with a subsequent definition of appropriate indicators and data needs.

\section{Hypothesis: Increased local participation or encompassing organization is associated}

with lower levels of conflict. Our indicators of political/associational organization must be treated with extreme caution, as these are not only some of the most difficult to measure, but also suffer significantly from endogeneity bias. For example, evidence of increased community association may act to reduce conflict (e.g., especially if as argued by Varshney these institutions are able to build bridges across communities). However, particular forms of group association may also lower the costs to mobilization, enhancing the likelihood of conflict. At the same time, associations may mobilize ex-post in response to a conflict, either to provide succor to reestablish community relations, or to perpetuate conflict. In sum, evidence of the role of local social capital defined broadly has been extremely difficult to establish in a compelling manner (Durlauf and Fafchamps 2004). Our proxies of formal or informal institutional factors should therefore not be interpreted to denote causality, but to spur better measurement (and empirical 
frameworks) for evaluations related to local conflict building on a mixed qualitative-quantitative approach.

The PODES survey collects information on village/neighborhood institutions. We have constructed variables which indicate the presence of religious groups, adat (traditional law/customs) institutions, and the number of places for worship. We also used variables that indicate whether there is a BPD in the village and the gender of the village head. The BPD is a mandated democratically elected council in rural areas.

Religious groups and adat institutions are associated with higher levels of conflict. One possible explanation may be that their presence reflects differences in norms about conflict resolution. The qualitative work indicated that often varying expectations between different groups in the community, or between the community and the state, about how tensions should be resolved resulted in conflict. The density of places of worship on the other hand is associated with lower levels of conflict, especially in rural areas. This may support Varshneys' hypothesis that institutions that can resolve tensions that exist between their constituencies play an important role in preventing conflict from arising and escalating. The absence of a BPD in a rural village has no effect on conflict in the regression with provincial dummies, but does appear to be associated with lower levels of conflict in the regression that does not include these controls. The presence of a female village leader is associated with lower level of conflict in rural areas. This however, is still a rare phenomena: only 2 percent of the rural communities had a female village leader.

\section{Hypothesis: Better public or communal provision of security is associated with lower}

conflict. The PODES allows us to construct variables concerning the presence of formal and informal security in a village, including whether the community has organized its own security 
(volunteers for poskambling (security posts), checkpoints to see who is entering the village), and the distance to the nearest police post. We find some evidence in rural areas that the presence of communal security arrangements is associated with a reduced likelihood of conflict. In contrast, distance to a police station reduces the likelihood of conflict. ${ }^{21}$ These associations must be interpreted with extreme caution, as this may actually reflect good targeting (posts are built nearer to likely trouble spots) or simply reflect that more isolated villages are less prone to conflict. These associations should provide an impetus to further on-going qualitative work to evaluate potential dynamics behind these associations, and subsequent means to better test these quantitatively.

\section{Conclusions}

The paper has presented the results of a unique large-scale effort in a developing country to monitor the incidence of local conflict, Indonesia's 2003 PODES. We found that conflict is significant across Indonesia, rather than being highly concentrated in just a few areas. This has significant implications for how we understand the roots of conflict in Indonesia. It suggests the need to investigate systemic factors associated with conflict, in addition to understanding often highly localized dynamics through qualitative approaches. From a policy perspective, the potential for conflict must be taken into account when designing development interventions for areas across Indonesia. From a research perspective, it implies the consideration and exploration of conflicts in areas beyond those normally thought of as being 'high conflict'.

\footnotetext{
${ }^{21}$ We also tested this with another variable that asked whether a police post was difficult to reach with similar results.
} 
The paper, in comparing the quantitative data with that gathered from a large-scale ethnographic World Bank study on conflict, has also hinted at some of the weaknesses of the PODES data. In particular, the comparison would suggest that PODES significantly underreports levels of conflict (both violent and not), and that this is true across the archipelago. The paper sets out two reasons for this: unclear definitions of conflict, and lack of incentives for respondents to be honest about conflict levels. We argued that the key question with regard to the usefulness of the data is whether under-reporting is biased (i.e. levels of under-reporting differ across locations) or whether it is systemic, with levels of underreporting similar across sites. We suggested that the latter is more likely to be the case, but that more research (perhaps by comparing different data sources on more areas) would need to be conducted to reach firm conclusions.

We conducted a quantitative analysis to find out which locally-specific factors are correlated with the presence of conflict. We found that poverty by itself has very little correlation with conflict. Changes in economic conditions, on the other hand do. Unemployment is universally closely associated with higher conflict rates; high in- and outward migration for work/school have similar positive associations with conflict. Our land variables indicate that the share of converted land in rural areas is associated with higher levels of conflict; the fraction of titled land has no correlation with conflict. The presence of a natural disaster is also clearly associated with higher conflict.

Much of the headline conflict in Indonesia is reported as clashes between ethnic groups. Only a small proportion (3.3\%) of conflict reported in PODES was described as being 'ethnic'. The 2000 Census for the first time collected self-reported ethnicity and we used this data to investigate the correlation between conflict and ethnicity. We find no evidence that increased 
ethnic diversity affects conflict. We do find that in areas where there is no single ethnic group dominant, conflict is more likely to be present. As expected, higher clustering of ethnic groups within villages across a sub-district is associated with higher levels of conflict. The main counter intuitive finding is that higher horizontal inequality, measured as the difference between the educational attainments of large ethnic groups, is associated with lower levels of conflict. Further research is needed to investigate the dynamic behind this correlation.

Institutions matter for mediating potential conflict. We investigated the correlation between the presence of institutions and conflict, but at the same time recognized that their very presence may result from conflict. We find that the density of places of worship is associated with lower levels of conflict, while the absence of a democratically elected village council (BPD) is associated with a higher conflict potential. Religious groups and traditional law institution, however, are associated with higher levels of conflict. This suggests that while formal institutions have a role in mediating between religious groups, informal institutions may flare up with conflict and/or negatively affect the scope for mediation as tensions rises. The presence of security posts is associated with lower levels of conflict in rural areas as is the distance from a police post.

A more systematic mapping of conflict should stimulate work on assessing the impacts of conflict in Indonesia, not just in high-profile conflict areas but beyond. An appreciation of the pervasive costs of conflict to individuals, firms, and society, and the incidence of these effects, will alert policy makers to the real costs of conflict. For example, while our research suggests that it is not the poorest communities that experience conflict, the disproportionate costs of conflict may actually fall on especially poor and vulnerable households. 
Future work along the lines presented in this paper will need to focus on a number of areas, including (a) improved methodologies and instrument implementation to measure the incidence of local conflict, (b) better empirical proxies at the local level to measure potential factors associated with conflict, and (c) increased attention to empirical research design to begin to address issues of causality.

With its national coverage, the BPS's PODES initiative provides an unprecedented insight with regards to the incidence of local conflict beyond those areas that have tended to capture the headlines. The PODES relies on village/neighborhood leadership as key respondents, under the assumption that these people are the most informed and able to report conflict at the local level. The approach potentially provides a systematic mapping of conflict by administrative area, something well beyond the ability of household surveys, given sampling requirements. As the paper points out, there may be certain factors that can cause underreporting of conflicts. In future enumerations of the survey, the statistical agents who implement the survey (mantri statistik) could be encouraged to cross-check the data on conflict with other key respondents, while at the same time gaining a better understanding of their reporting incentives. Additional work might compare these results with more targeted surveys of household respondents in a subset of localities. ${ }^{22}$ We would therefore certainly recommend that BPS retain the local conflict module in the 2005 PODES, but that it consider some refinements to the

\footnotetext{
${ }^{22}$ At the time of writing, the University of Gadjah Mada in Yogya with the World Bank is implementing a household survey in an estimated six hundred villages that includes some refined conflict questions.
} 
module in terms of definitions/thresholds, sequencing of questions, and the training of statistical agents. $^{23}$

Our paper has presented a number of potential measures for local level inequality, diversity, and group inequality. Future qualitative work might gain a better understanding of group dynamics at the local level, and how these could be mapped in local indicators (for example from the Population Census), and then mapped across datasets. Similar efforts should be made in devising simple but effective proxies for the effectiveness of local institutions that might help mediate conflict. We have argued that quantitative work is at this stage only effective in identifying underlying associations with conflict. Qualitative work can help in identifying pathways and directions of causality. In a mixed quantitative-qualitative framework (Rao and Woolcock 2003), future refinements of the quantitative evidence and methodological frameworks could lead to better hypothesis testing and the derivation of potential policy findings. This paper is but an initial presentation of the results and implications of the 2003 PODES on conflict. We hope that it will stimulate further debates and consideration, both of the causes of

\footnotetext{
${ }^{23}$ First, the definitions - of conflict and its types - should be clearer in the instrument. At present, it is unclear what exactly is meant by conflict. For example rephrasing the guidance for the question about whether conflict existed in the village, refining its parameters, perhaps by setting a minimum threshold for incidents that should be included, would better ensure consistency of reporting. For example, respondents could be asked "has there been a conflict in the past year in this village in which at least one person was killed or injured, or in which there was damage of property or goods?" This would help ensure that there is a common understanding of conflict amongst respondents, and would hence limit biased under-reporting, giving us more confidence in the resulting data. More accurate descriptors for conflict and crime types would also help in this respect. Second, the ordering of questions might help with the incentives question. If questions are carefully ordered, with 'gentler' less sensitive questions coming first, at least some level of trust can be built between interviewer and interviewee, perhaps resulting in more open responses. Other techniques such as using enumerators who speak local languages, and explaining in more detail what the survey will be used for (and what it will not), can also help. A third recommendation, which would show more clearly trends over time, as well as capture more of the social tensions that exist in villages, would be to ask the respondents not just to recall conflicts that took place in the last year, but also those that occurred in the two years before that.
} 
conflict in Indonesia, and of the methodological tools we can use to measure and understand local conflict more generally. 


\section{References}

Alesina, Alberto, et al. 2003. "Fractionalization." JEG:8, pp. 155-94.

Antlov, Hans. 2001. "Village Governance and Local Politics in Indonesia." Paper presented at session on Decentralization and Democratization in Southeast Asia at SOAS, London, 6th-9th September 2001: London.

Barron, Patrick, et al. 2004a. "Do Participatory Development Projects Help Villagers Manage Local Conflicts? A Mixed Methods Approach to Assessing the Kecamatan Development Project, Indonesia." Social Development Department, Environmentally and Socially Sustainable Development Network: Washington, DC, CPR Working Paper No. 9 (Revised Edition), (March).

Barron, Patrick and David Madden. 2003. "Violence \& Conflict Resolution in "Non-Conflict" Regions: The Case of Lampung, Indonesia." World Bank, East Asia and Pacific Unit: Washington D.C.

Barron, Patrick, et al. 2004b. "Understanding Local Level Conflict Pathways in Developing Countries: Theory, Evidence and Implications from Indonesia." 42. mimeo: Washington, DC.

Bates, Robert. 2000. Violence and Prosperity: The Political Economy of Development. New York: Norton.

Bennet, Chris P.A. 2002. "Toward resolution of conflict between customary (adat) land rights and state land management through greater transparency of land information." Paper presented at a meeting on 'The Perspective of Customary Land Rights in Approaches to Comprehensively Resolve Land Conflicts', 19-20 June, 2002, Ministry of Home Affairs, Jakarta.: Jakarta.

Chua, Amy. 2002. World on Fire: How Exporting Free Market Democracy Breeds Ethnic Hatred and Global Instability: Doubleday.

Collier, Paul. 2001. "Ethnic diversity: An Economic Analysis." Economic Policy, pp. 128-66.

Collier, Paul. 2002. "Greed and Grievance in Civil War." 44. Center for the Study of African Economies: Oxford, Working Paper 2002-1, (March 13th).

Demombynes, Gabriel and Berk Ozler. 2002. "Crime and Local Inequality in South Africa." 62. World Bank: Washington, DC, Policy Research Working Paper, (November).

Durlauf, Steven N. and Marcel Fafchamps. 2004. "Empirical Studies of Social Capital: A Critical Survey." 89. University of Wisconscin and Oxford University, (April 28).

Easterly, William and Ross Levine. 1997. "Africa's Growth Tragedy: Policies and Ethnic Divisions." QJE:November, pp. 1203-50. 
Fajnzylber, Pablo, et al. 2002. "Inequality and Violent Crime." Journal of Law and Economics, XLV:April.

Gurr, Ted Robert, et al. 2001. "Peace and Conflict 2001: A Global Survey of Armed Conflicts, Self-Determination Movements, and Democracy." Center for International Development and Conflict Management: University of Maryland.

Humphreys, Macartan. 2003. "Economics and Violent Conflict." Cambridge, MA.

Iceland, John. 2002. "Beyond Black and White: Metropolitan Residential Segregation in MultiEthnic America." 28. Housing and Household Economic Statistics Division, US Census Bureau: Washington, DC, Paper presented at American Sociological Association meetings, (August).

ICG. 2001. "Indonesia: Natural Resources and Law Enforcement." International Crisis Group: Jakarta/Brussels.

ICG. 2003. "Indonesia: Managing Decentralization and Conflict in Indonesia." 44. International Crisis Group: Jakarta/Brussels, ICG Asia Report, (18 July).

Kaiser, Kai and Jack Molyneaux. 2000. "RAND Indonesia Data Core On-Line Documentation." RAND: Santa Monica, http://www.rand.org/organization/drd/labor/bps.data/index.htm.

Long, J. Scott and Jeremy Freese. 2003. Regression Models for Categorical Dependent Variables Using STATA. College Station, Texas: STATA Corporation.

Malley, Michael. 2001. "Social Cohesion and Conflict Management in Indonesia," in Social Cohesion and Conflict Prevention in Asia : Managing Diversity through Development. Anita Kelles-Viitanen, Nat J. Colletta and Teck Gee Lim eds. Washington, DC and Manila.

Miguel, Edward A., et al. 2003. "Did Industrialization Destroy Social Capital in Indonesia?" 50 + Annexes. Institute of Business and Economic Research, Center for International and Development Economics Research: Berkeley, CA, Paper C03.131.

Miguel, Edward and Mary Kay Gugerty. 2002. "Ethnic Diversity, Social Sanctions, and Public Goods in Kenya." 52. U California Berkeley/U Washington: Berkeley/Seattle, (December).

Rao, Vijayendra and Michael Woolcock. 2003. "Integrating Qualitative and Quantitative Approaches in Program Evaluation," in The Impacts of Economic Policies on Poverty and Income Distribution: Evaluating Techniques and Tools. François Bourguignon and Luiz A. Pereira da Silva eds. Oxford/Washington: Oxford University/World Bank, pp. $165-90$.

Reardon, Sean F. and Glenn Firebaugh. 2002. "Measures of Multigroup Segregation." Sociological Methodology:32, pp. 33-67. 
Reardon, Sean F., et al. 2000. "The Changing Structure of School Segregation: Measurement and Evidence of Multiracial Metropolitan-Area School Segregation, 1989-1995."

Demography, 37:3, pp. 351-64.

Ross, Michael. 2002. "Resources and Rebellion in Aceh, Indonesia." Paper prepared for the Yale University-World Bank Case Study Project on the Political Economy of Civil Wars.

Singer, David J. 1990. Models, Methods, and Progress: A Peace Research Odyssey. Boulder: Westview Press.

Smith, Claire. 2003. "Conflict and Conflict Resolution at the Local Level: Case Studies from Central Kalimantan , East Java, and Lampung." World Bank Office (mimeo): Jakarta.

Stewart, Frances. 2002. "Horizontal Inequalities: A Neglected Dimension of Development." Queen Elizabeth House, Univeristy of Oxford: Oxford, QEH Working Paper no. 81.

Tadjoeddin, Mohammad Zulfan. 2002. "The Anatomy of Collective Violence in Indonesia: During the Transition to Democracy, 1998-2000." United National Special Facility for Indonesian Recovery (UNSFIR) Working Paper No 2/01: Jakarta.

Tadjoeddin, Mohammad Zulfan, et al. 2001a. "Regional Disparity and Vertical Conflict in Indonesia." Journal of the Asia Pacific Economy, 6:3, pp. 283-304.

Tadjoeddin, Mohammad Zulfan, et al. 2001b. "Regional Disparity and Vertical Conflict in Indonesia." 38. UNDP/UNSFIR (United National Special Facility for Indonesian Recovery): Jakarta, mimeo.

Tule, Philipus. 2000. "Religious Conflicts and a Culture of Tolerance: Paving the Way for Reconciliation in Indonesia." Antropologi Indonesia:63.

Wallensteen, Peter and Margaerta Sollenburgh. 1998. "Armed Conflict and Regional Conflict Complexes: 1989-1997." Journal of Peace Research, 35:5.

Welsh, Bridget. 2003. "Street Justice: Vigilantism in West Java." Paper prepared for the Workshop on Contentious Politics, Columbia University, New York.

Wetterberg, Anna. 2002. "Social Capital, Local Capacity, and Government: Findings from the Second Indonesian Local Level Institutions Study." World Bank, mimeo: Jakarta.

Wilson, C. 2001. "Internal Conflict in Indonesia: Causes, Symptoms and Sustainable Resolution." Parliament of Australia. Research Paper 1 2001-2002. Available at <www.aph.gov.au/library/pubs/rp/2001 02RP01.htm>: Canberra.

World Bank. 2003a. "Breaking the Conflict Trap: Civil War and Development Policy." 221. World Bank: Washington, DC.

World Bank. 2003b. "Land Policies for Growth and Poverty Reduction." 239. World Bank: Washington, DC. 


\section{Annex 1: Measures of Group Diversity and Inequality}

\section{Diversity Measures}

To measure ethnic or religious diversity, we apply the Theil multi-group segregation index as presented in (Reardon, et al. 2000):

$$
E=\sum_{m=1}^{M} \pi_{m} \ln \left(\frac{1}{\pi_{m}}\right)
$$

where $\pi_{m}$ is defined as the share of ethnic class $m$ in the total population. ${ }^{24}$ A high value of the index indicates more ethnic diversity. If all the population is from one group, i.e. $\pi_{m}=1$ for $m=j$ and $\pi_{m}=0$ for $m \neq j$, the index reaches its lowest value of zero. The upper bound depends on the numbers of ethnic groups.

The Theil index is similar to the Ethnolinguistic Fractionalization (ELF) measure used in much of the international literature (Alesina, et al. 2003). The measure equals one minus the sum of individual group shares. ELF measures the probability of two individuals in an area coming from the same group. The measure is effectively the inverse of a Herfindahl measure. Zero entails high homogeneity, whereas a maximum of one entails that all individuals come from a different group.

\section{Ethnic Clustering/Segregation}

While the ELF is at first sight easier to interpret, the Theil has a number of attractive statistical properties, including the ability to construct measures of the ethnic and religious segregation (or "clustering") (Reardon and Firebaugh 2002; Reardon, et al. 2000). A further advantage is that it can be decomposed to capture individual group contributions (Iceland 2002). The decomposed Theil index (H) compares how diverse sub-areas in a given area as a whole (e.g., villages relative to the sub-district). The index ranges from 0 (little "clustering") to 1 (if no member of the same group lives in the same sub-area as another sub-member).

$$
H_{i}=\frac{\sum_{j=1}^{J} \pi_{j i}\left(E_{i}-E_{j}\right)}{E_{i}}=\sum_{m=1}^{M} \sum_{j=1}^{J} \frac{t_{j}}{T E} \pi_{j m} \ln \left(\frac{\pi_{j m}}{\pi_{m}}\right)
$$

Where $t_{j}$ is the population in sub-area (e.g., village) $j$, and $T=$ the total population in the area (e.g., sub-district). The ethnic segregation index is based on comparing the shares of an ethnicity in a sub-jurisdiction (e.g., village) $\left(\pi_{j m}\right)$ to its overall share in a jurisdiction

\footnotetext{
${ }^{24}$ Note that $\sum_{m=1}^{M} 0 \ln \left(\frac{1}{0}\right) \rightarrow 0$ so that one needs to sum only over the ethnic groups that are observed.
} 
(e.g., sub-district) $r_{j m}=\left(\frac{\pi_{j m}}{\pi_{m}}\right)$ that is, the share of ethnic group $m$ in village $j$ as a proportion of the share of that ethnic group in the whole population in the sub-district. If $r_{j m}=1$ for all $j$ and $m$, all ethnic groups are evenly distributed across villages and the index equals zero. Note that it is not an indication of whether one group is more dominant than the other. Ethnic dominance is defined by the share in the population of the largest group

\section{Dominance}

We measure dominance based on the share of the largest self-reported group in a jurisdiction.

$$
S_{r}=\max _{m}\left(\pi_{r m}\right)
$$

\section{Local Inequality}

In the absence of consumption or income measures by group and/or locality, we used educational attainment from the census as a measure of wealth, for males aged 20-30 in the kecamatan (sub-district). The standard deviation is used as the inequality measure.

\section{Horizontal Inequality}

Our measure of horizontal group inequality measures the most to least educationally endowed group in a jurisdiction (e.g., sub-district), based on years of schooling by household heads.

$H I_{m=} \frac{\max _{m}\left(e d u c_{m r}\right)}{\min _{m}\left(e d u c_{m r}\right)} * 100$, with $m$ denoting groups that represent at least 10 percent of the 


\section{Annex 2: PODES Politics and Security Module}

\section{POLITIK DAN KEAMANAN POLITICS AND SECURITY}

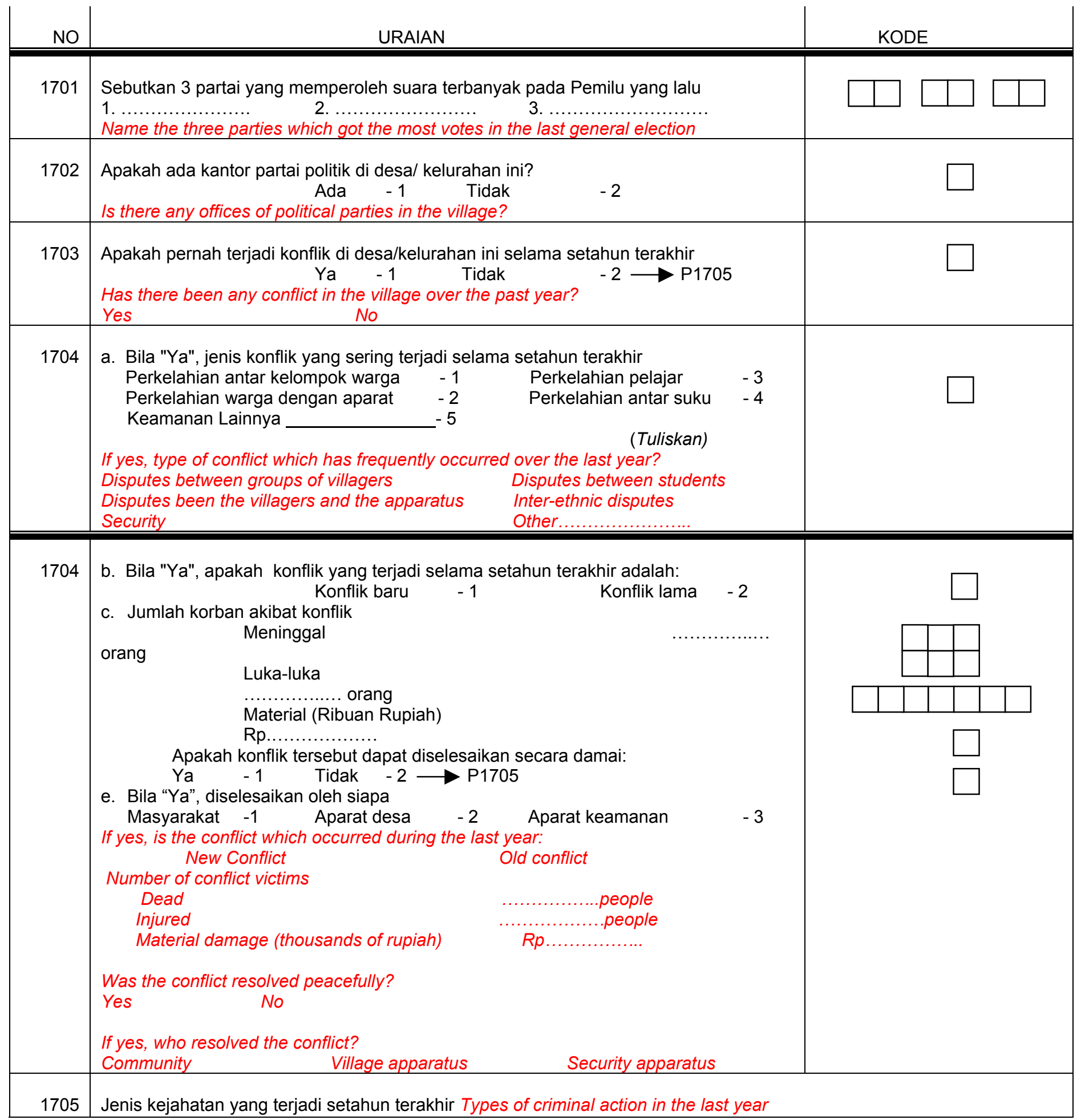




\begin{tabular}{|c|c|c|c|c|c|}
\hline & \multirow{2}{*}{\multicolumn{2}{|c|}{ Jenis kejahatan }} & \multicolumn{2}{|c|}{$\begin{array}{l}\text { Apakah ada } \\
\text { Kasus } \\
\text { Ya }-1 \\
\text { Tidak }-2\end{array}$} & 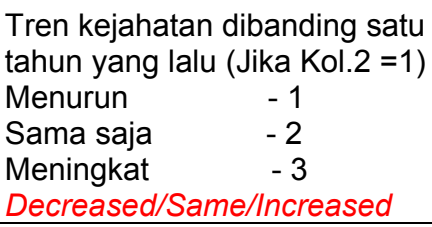 \\
\hline & & & \multicolumn{2}{|l|}{$(2)$} & $(3)$ \\
\hline & \multicolumn{2}{|c|}{$\begin{array}{l}\text { Pencurian Stealing } \\
\text { Perampokan Robbery } \\
\text { Penjarahan Plundering } \\
\text { Penganiayaan/kekerasan Torture/Violence } \\
\text { Pembakaran Arson } \\
\text { Perkosaan Rape } \\
\text { Narkoba Narcotics } \\
\text { Pembunuhan Murder } \\
\text { Lainnya Other } \\
\quad \text { (Tuliskan) }\end{array}$} & & & \\
\hline \multirow[t]{4}{*}{1706} & \multicolumn{4}{|c|}{$\begin{array}{l}\text { Apakah ada penduduk yang bunuh diri setahun terakhir: } \\
\text { Ya } \\
\text { Has there been a villager who committed suicide in the last year: Yes }\end{array}$} & \\
\hline & \multirow{2}{*}{\multicolumn{2}{|c|}{$\begin{array}{l}\text { Korban bunuh diri yang terjadi setahun terakhir } \\
\text { Suicide victims in the last year } \\
\text { (1) }\end{array}$}} & \multicolumn{2}{|l|}{$\begin{array}{c}\text { Laki-Laki } \\
\text { Male }\end{array}$} & $\begin{array}{l}\text { Perempuan } \\
\text { Female }\end{array}$ \\
\hline & & & \multicolumn{2}{|l|}{$(2)$} & (3) \\
\hline & \multicolumn{2}{|l|}{$\begin{array}{l}\text { Anak-anak Children } \\
\text { Remaja Teenagers } \\
\text { Dewasa Adults }\end{array}$} & & & \\
\hline 1707 & \multicolumn{4}{|c|}{ 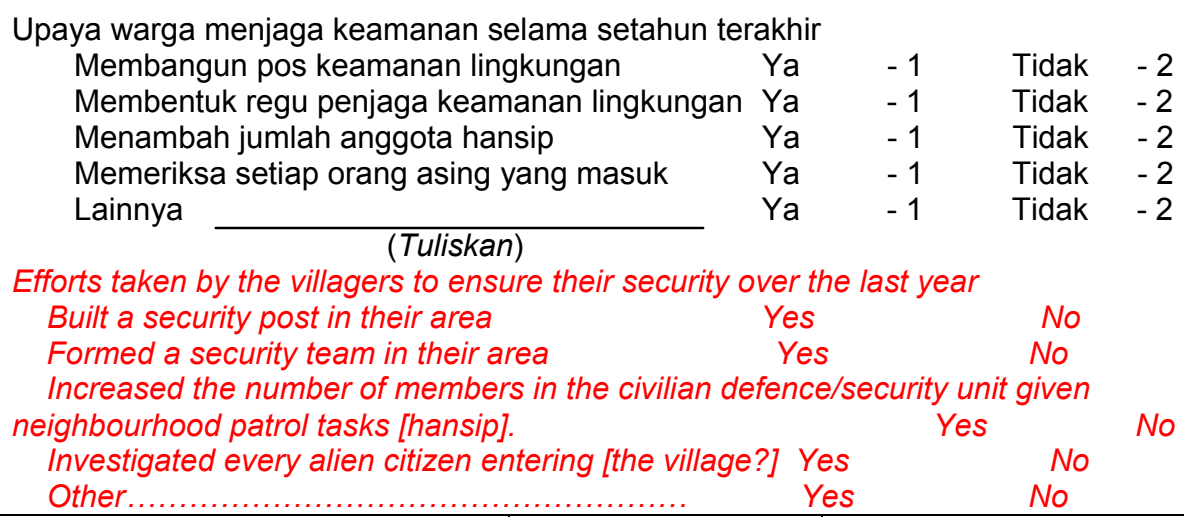 } & 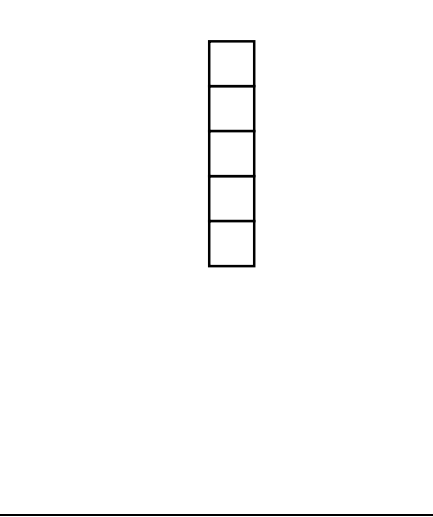 \\
\hline \multirow{3}{*}{1708} & \multicolumn{5}{|c|}{\begin{tabular}{l|l|c|} 
& Jika "Tidak ada" \\
\end{tabular}} \\
\hline & $\begin{array}{l}\text { Sarana keamanan } \\
\text { Lingkungan (kamling) } \\
\text { Neighbourhood law and order } \\
\text { units }\end{array}$ & $\begin{array}{l}\text { Ada } \quad-1 \\
\text { Tidak ada }-2 \\
\text { Exists } \\
\text { Non-existent }\end{array}$ & \multicolumn{2}{|l|}{$\begin{array}{l}\text { Jarak terdekat } \\
\quad(\mathrm{km}) \\
\text { closest distance }\end{array}$} & \multirow[t]{2}{*}{\begin{tabular}{ll} 
Kemudahan untuk mencapai \\
Sangat mudah & -1 \\
Mudah & -2 \\
Sulit & -3 \\
Sangat sulit & -4 \\
Accessibility & \\
Very easy & \\
Easy & \\
Difficult & \\
Very difficult \\
\multicolumn{2}{c|}{$(4)$} \\
\end{tabular}} \\
\hline & (1) & $(2)$ & (3) & & \\
\hline
\end{tabular}




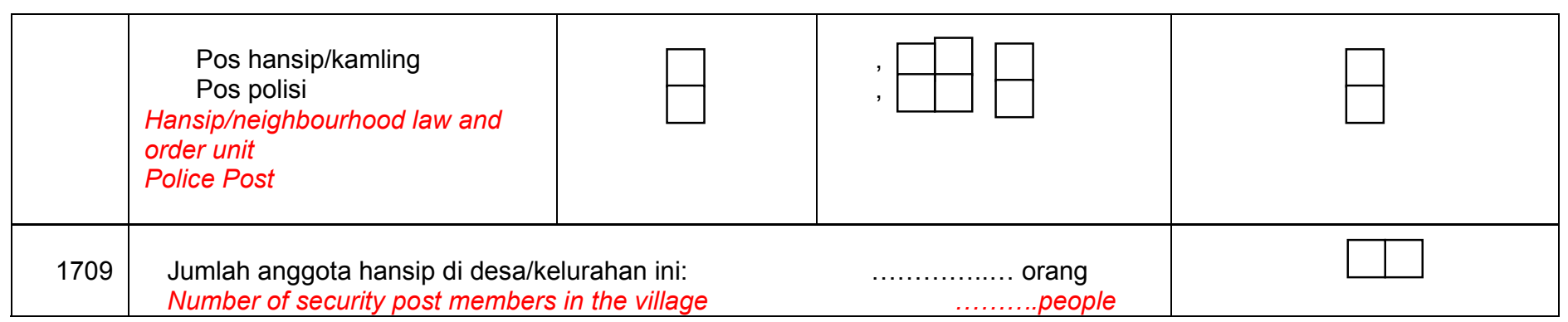

Source: Central Bureau of Statistics (BPS) 
Table 3: Conflict Incidence by Province

\begin{tabular}{|c|c|c|c|c|}
\hline & Conflict (\%) & $\begin{array}{l}\text { Conflict } \mathrm{w} / \\
\text { casualties/material } \\
\text { damage }(\%)\end{array}$ & $\begin{array}{l}\text { New Conflict } \\
\text { (\%) }\end{array}$ & $\begin{array}{l}\text { Violent/All } \\
\text { Conflict (\%) }\end{array}$ \\
\hline Aceh & 23.4 & 14.1 & 3.0 & 60.2 \\
\hline North Sumatra & 4.1 & 2.8 & 2.9 & 68.6 \\
\hline West Sumatra & 6.6 & 4.9 & 5.4 & 74.1 \\
\hline Riau & 5.4 & 3.3 & 3.9 & 61.4 \\
\hline Jambi & 6.0 & 3.4 & 4.7 & 57.7 \\
\hline South Sumatra & 2.3 & 1.5 & 1.6 & 64.5 \\
\hline Bengkulu & 2.6 & 0.9 & 2.0 & 36.7 \\
\hline Lampung & 3.5 & 2.3 & 3.0 & 64.9 \\
\hline Bangka Belitung & 12.3 & 8.8 & 10.4 & 71.8 \\
\hline Jakarta & 13.5 & 6.7 & 6.0 & 50.0 \\
\hline West Java & 7.9 & 5.7 & 5.5 & 72.5 \\
\hline Central Java & 5.8 & 3.8 & 4.5 & 65.5 \\
\hline Yogya & 5.0 & 2.5 & 3.9 & 50.0 \\
\hline East Java & 3.5 & 2.3 & 2.6 & 64.0 \\
\hline Banten & 3.0 & 1.9 & 2.8 & 62.2 \\
\hline Bali & 7.6 & 3.9 & 6.3 & 51.9 \\
\hline NTB & 13.8 & 9.5 & 10.7 & 68.6 \\
\hline NTT & 11.6 & 6.0 & 8.5 & 51.5 \\
\hline West Kalimantan & 4.0 & 1.5 & 3.4 & 38.6 \\
\hline Central Kalimantan & 2.4 & 1.3 & 1.7 & 53.1 \\
\hline South Kalimantan & 1.4 & 0.6 & 1.1 & 40.7 \\
\hline East Kalimantan & 4.5 & 2.3 & 3.8 & 51.7 \\
\hline North Sulawesi & 10.9 & 7.2 & 8.1 & 66.2 \\
\hline Central Sulawesi & 11.9 & 8.7 & 6.7 & 73.1 \\
\hline South Sulawesi & 5.7 & 3.8 & 3.5 & 66.7 \\
\hline SE Sulawesi & 5.6 & 4.0 & 4.5 & 72.4 \\
\hline Gorontalo & 2.4 & 1.1 & 2.1 & 44.4 \\
\hline Maluku & 15.6 & 9.4 & 8.6 & 60.3 \\
\hline North Maluku & 12.6 & 8.8 & 7.4 & 69.9 \\
\hline Papua & 3.3 & 1.8 & 2.1 & 52.6 \\
\hline
\end{tabular}

Source: PODES 2003 
Table 7: Descriptives

\begin{tabular}{|c|c|c|c|c|c|}
\hline & Source & rural & & urban & \\
\hline & & mean & std. Dev & mean & std.dev \\
\hline Conflict & Podes & 0.07 & 0.25 & 0.09 & 0.29 \\
\hline Conflict w/ casualties/material damage reported & Podes & 0.04 & 0.20 & 0.06 & 0.23 \\
\hline $\begin{array}{l}\text { Absolute Poverty: District poverty gap based on per } \\
\text { capita consumption }\end{array}$ & Susenas & 5.59 & 5.32 & 3.90 & 3.59 \\
\hline $\begin{array}{l}\text { Relative Poverty: Village poverty/district poverty - } \\
\text { BKKBN }\end{array}$ & Podes & 1.01 & 0.53 & 0.90 & 0.64 \\
\hline Inequality in Educ Attainment (sd Years Males 20-30) & Census & 3.39 & 0.44 & 3.66 & 0.38 \\
\hline Change in Poverty: Increase in $\mathrm{Nr}$ of poor -BKKBN & Podes & 0.34 & 0.47 & 0.35 & 0.48 \\
\hline $\begin{array}{l}\text { Natural disaster: earthquake, land slide or flood in past } \\
3 \text { years }\end{array}$ & t Podes & 0.26 & 0.44 & 0.31 & 0.46 \\
\hline Fraction of individuals unemployed in village & Podes & 0.04 & 0.06 & 0.04 & 0.07 \\
\hline Share of families that do not work in agriculture & Podes & 0.19 & 0.20 & 0.64 & 0.36 \\
\hline $\begin{array}{l}\text { There are families who live outside village for work or } \\
\text { study }\end{array}$ & Podes & 0.96 & 0.19 & 0.98 & 0.15 \\
\hline $\begin{array}{l}\text { There are families who have moved to this village for } \\
\text { work or study }\end{array}$ & Podes & 0.67 & 0.47 & 0.90 & 0.30 \\
\hline $\begin{array}{l}\text { Share land converted to different economic use in past } \\
3 \text { years }\end{array}$ & Podes & 0.013 & 3.130 & 0.024 & 0.239 \\
\hline Mining is main source of income in village & Podes & 0.003 & 0.051 & 0.007 & 0.086 \\
\hline Forestry is main source of income in village & Podes & 0.012 & 0.110 & 0.004 & 0.059 \\
\hline Share of private agricultural land that is non-titled & Podes & 0.52 & 0.36 & 0.47 & 0.35 \\
\hline $\begin{array}{l}\text { Community land ownership structure } \\
\text { reported(dummy) }\end{array}$ & Podes & 0.26 & 0.44 & 0.38 & 0.49 \\
\hline More than one ethnic group in the village & Podes & 0.59 & 0.49 & 0.86 & 0.35 \\
\hline More than one religion in the kecamatan & Podes & 0.23 & 0.42 & 0.20 & 0.40 \\
\hline $\begin{array}{l}\mathrm{Nr} \text { of places of worship in village / } \mathrm{nr} \text { of families in } \\
\text { village }\end{array}$ & Podes & 0.018 & 0.016 & 0.010 & 0.008 \\
\hline Ethnically Diverse Sub-District (Theil measure) & Census & 0.70 & 0.70 & 1.17 & 0.82 \\
\hline $\begin{array}{l}\text { Clustering of ethnic groups across villages in } \\
\text { kecamatan }\end{array}$ & Census & 0.28 & 0.16 & 0.18 & 0.13 \\
\hline Largest ethnic group in kec has pop share less $40 \%$ & Census & 0.10 & 0.30 & 0.27 & 0.44 \\
\hline $\begin{array}{l}\text { Horizontal inequality: (Max/Min Group HH Head } \\
\text { Education in Kecamatan) }\end{array}$ & Census & 111.07 & 29.46 & 113.91 & 20.66 \\
\hline There are marriages across ethnicity in this village & Podes & 0.63 & 0.48 & 0.84 & 0.37 \\
\hline $\begin{array}{l}\text { There is no BPD - elected village council - in the } \\
\text { village }\end{array}$ & Podes & 0.20 & 0.40 & 0.00 & 0.00 \\
\hline Village leader is female & Podes & 0.02 & 0.14 & 0.04 & 0.20 \\
\hline There are religious groups in the village & Podes & 0.07 & 0.26 & 0.09 & 0.29 \\
\hline There are traditional (adat) institutions in the village & Podes & 0.39 & 0.49 & 0.32 & 0.47 \\
\hline Community security organization exists in village & Podes & 0.84 & 0.37 & 0.94 & 0.24 \\
\hline Distance to nearest police post & Podes & 11.23 & 16.99 & 3.58 & 9.29 \\
\hline
\end{tabular}


Table 8: Estimation Results

\begin{tabular}{|c|c|c|c|c|c|c|c|c|}
\hline & (1) & (2) & (3) & (4) & (5) & (6) & (7) & (8) \\
\hline & $\begin{array}{l}\text { Rural, } \\
\text { ex-Aceh }\end{array}$ & $\begin{array}{l}\text { Urban, } \\
\text { ex-Aceh }\end{array}$ & Rural,ex_Aceh & $\begin{array}{l}\text { Urban, } \\
\text { ex-Aceh }\end{array}$ & $\begin{array}{l}\text { Rural, } \\
\text { incl. } \\
\text { Aceh }\end{array}$ & $\begin{array}{l}\text { Urban, } \\
\text { incl. } \\
\text { Aceh }\end{array}$ & $\begin{array}{l}\text { Rural, } \\
\text { East } \\
\text { Java }\end{array}$ & $\begin{array}{l}\text { Rural, } \\
\text { NTT }\end{array}$ \\
\hline Regional Dummies & Yes & Yes & No & No & No & No & No & No \\
\hline $\begin{array}{l}\text { Absolute Poverty: } \\
\text { District poverty gap } \\
\text { based on per capita } \\
\text { consumption SU }\end{array}$ & 0.007 & 0.015 & 0.030 & 0.043 & 0.001 & 0.014 & -0.120 & 0.056 \\
\hline & $(0.55)$ & $(0.65)$ & $(3.57)^{* *}$ & $(2.75)^{* *}$ & $(0.09)$ & $(0.64)$ & $(2.88)^{* *}$ & (1.69) \\
\hline $\begin{array}{l}\text { Relative Poverty: } \\
\text { Village } \\
\text { poverty/district } \\
\text { poverty PO-BKKBN }\end{array}$ & 0.009 & -0.085 & 0.023 & -0.112 & -0.004 & -0.086 & -0.083 & -0.119 \\
\hline & $(0.15)$ & $(0.90)$ & $(0.42)$ & $(1.14)$ & $(0.05)$ & $(0.92)$ & $(0.35)$ & $(0.39)$ \\
\hline $\begin{array}{l}\text { Inequality in Educ } \\
\text { Attainment (sd Years } \\
\text { Males 20-30) CE }\end{array}$ & 0.308 & -0.151 & 0.229 & -0.188 & 0.025 & -0.188 & -0.167 & -0.379 \\
\hline & $(2.72)^{* *}$ & $(0.63)$ & $(2.14)^{*}$ & $(0.95)$ & $(0.16)$ & $(0.81)$ & $(0.47)$ & $(1.16)$ \\
\hline $\begin{array}{l}\text { Change in Poverty: } \\
\text { Increase in Nr of poor } \\
\text { PO-BKKBN }\end{array}$ & 0.113 & 0.168 & 0.137 & 0.178 & 0.133 & 0.159 & -0.038 & -0.229 \\
\hline Natural disaster: & $\begin{array}{l}(1.96) \\
0.289\end{array}$ & $\begin{array}{l}(1.61) \\
0.435\end{array}$ & $\begin{array}{c}(2.34)^{*} \\
0.275\end{array}$ & $\begin{array}{l}(1.70) \\
0.353\end{array}$ & $\begin{array}{c}(1.78) \\
0.278\end{array}$ & $\begin{array}{l}(1.53) \\
0.390\end{array}$ & $\begin{array}{l}(0.24) \\
0.497\end{array}$ & $\begin{array}{l}(1.05) \\
0.102\end{array}$ \\
\hline & $(4.48)^{* *}$ & $(3.77)^{* *}$ & $(4.27)^{* *}$ & $(3.18)^{* *}$ & $(3.13)^{* *}$ & $(3.39)^{* *}$ & $(3.18)^{* *}$ & $(0.45)$ \\
\hline $\begin{array}{l}\text { Fraction of } \\
\text { individuals } \\
\text { unemployed in village } \\
\text { PO }\end{array}$ & 1.092 & 1.378 & 1.192 & 1.800 & 0.923 & 1.448 & 0.126 & 1.906 \\
\hline & $(3.02)^{* *}$ & $(2.29)^{*}$ & $(3.25)^{* *}$ & $(2.96)^{* *}$ & $(1.90)$ & $(2.45)^{*}$ & $(0.09)$ & (1.11) \\
\hline $\begin{array}{l}\text { Share of families that } \\
\text { do not work in } \\
\text { agriculture PO }\end{array}$ & 0.099 & 0.262 & 0.222 & -0.050 & 0.080 & 0.118 & (1.46) & $(0.66)$ \\
\hline $\begin{array}{l}\text { There are families } \\
\text { who live outside } \\
\text { village for work or } \\
\text { study PO }\end{array}$ & $(2.09)^{*}$ & 0.677 & $(2.23)^{*}$ & 0.614 & $(2.73)^{* *}$ & $(1.35)$ & & (1.84) \\
\hline $\begin{array}{l}\text { There are families } \\
\text { who have moved to } \\
\text { this village for work } \\
\text { or study PO }\end{array}$ & 0.295 & -0.001 & 0.288 & 0.034 & 0.257 & -0.002 & 0.244 & 0.310 \\
\hline $\begin{array}{l}\text { Share land converted } \\
\text { to different economic } \\
\text { use in past } 3 \text { years PO }\end{array}$ & 0.587 & 0.750 & 0.471 & 0.412 & 0.458 & (1.43) & $(0.47)$ & $(2.26)^{*}$ \\
\hline $\begin{array}{l}\text { Mining is main source } \\
\text { of income in village } \\
\text { PO }\end{array}$ & 0.063 & 0.511 & 0.126 & 0.491 & 0.114 & 0.509 & 2.793 & \\
\hline $\begin{array}{l}\text { Forestry is main } \\
\text { source of income in } \\
\text { village PO }\end{array}$ & $\begin{array}{c}(0.17) \\
-0.404\end{array}$ & $(0.94)$ & $\begin{array}{l}(0.39) \\
-0.565\end{array}$ & $(0.78)$ & $\begin{array}{c}(0.30) \\
-0.344\end{array}$ & $(0.93)$ & $(4.73)^{* *}$ & 0.986 \\
\hline Share of private & 0.110 & -0.179 & 0.112 & -0.440 & 0.181 & -0.115 & -0.141 & 0.517 \\
\hline
\end{tabular}


Table 8: Estimation Results (cont)

\begin{tabular}{|c|c|c|c|c|c|c|c|c|}
\hline \multicolumn{9}{|l|}{$\begin{array}{l}\text { agricultural land that } \\
\text { is non-titled PO }\end{array}$} \\
\hline \multirow{3}{*}{$\begin{array}{l}\text { Community land } \\
\text { ownership structure } \\
\text { reported(dummy) PO }\end{array}$} & $\begin{array}{r}(1.28) \\
-0.170\end{array}$ & $\begin{array}{l}(0.86) \\
-0.120\end{array}$ & $\begin{array}{l}(1.32) \\
-0.155\end{array}$ & $\begin{array}{l}(2.19)^{*} \\
-0.196\end{array}$ & $\begin{array}{l}(1.90) \\
-0.257\end{array}$ & $\begin{array}{l}(0.57) \\
-0.095\end{array}$ & $\begin{array}{l}(0.55) \\
-0.100\end{array}$ & $\begin{array}{l}(1.52) \\
0.577\end{array}$ \\
\hline & & & & & & & & \\
\hline & $(1.80)$ & $(0.92)$ & $(1.70)$ & $(1.40)$ & $(2.33)^{*}$ & $(0.73)$ & $(0.34)$ & $(1.51)$ \\
\hline \multirow{2}{*}{$\begin{array}{l}\text { More than one ethnic } \\
\text { group in the village } \\
\text { PO }\end{array}$} & 0.019 & -0.056 & -0.009 & 0.003 & 0.060 & -0.077 & -0.202 & 0.018 \\
\hline & $(0.27)$ & $(0.31)$ & $(0.12)$ & $(0.02)$ & $(0.80)$ & $(0.45)$ & $(0.93)$ & $(0.08)$ \\
\hline \multirow{2}{*}{$\begin{array}{l}\text { More than one } \\
\text { religion in the } \\
\text { kecamatan PO }\end{array}$} & -0.044 & 0.103 & 0.190 & 0.330 & -0.161 & 0.088 & -0.965 & -0.329 \\
\hline & $(0.41)$ & $(0.61)$ & $(2.06)^{*}$ & $(2.15)^{*}$ & $(1.40)$ & $(0.53)$ & $(1.75)$ & (1.17) \\
\hline \multirow{2}{*}{$\begin{array}{l}\mathrm{Nr} \text { of places of } \\
\text { worship in village / } \mathrm{nr} \\
\text { of families in village } \\
\text { PO }\end{array}$} & -24.390 & -10.588 & -27.249 & -18.618 & -17.331 & -10.684 & -10.811 & $\begin{array}{c}- \\
41.320\end{array}$ \\
\hline & $(7.23)^{* *}$ & $(1.28)$ & $(7.67)^{* *}$ & $(2.20)^{*}$ & $(4.80)^{* *}$ & $(1.32)$ & $(1.62)$ & $(2.11)^{*}$ \\
\hline \multirow{2}{*}{$\begin{array}{l}\text { Ethnicaly Diverse } \\
\text { Sub-District (Theil } \\
\text { measure) CE }\end{array}$} & -0.027 & -0.050 & -0.073 & 0.193 & -0.271 & -0.057 & -1.369 & 0.849 \\
\hline & $(0.23)$ & $(0.33)$ & $(0.83)$ & $(1.39)$ & $(1.99)^{*}$ & $(0.39)$ & $(1.76)$ & $(2.09)^{*}$ \\
\hline \multirow{2}{*}{$\begin{array}{l}\text { Clustering of ethnic } \\
\text { groups across villages } \\
\text { in kecamatan CE }\end{array}$} & 1.497 & 0.537 & 1.442 & 0.662 & 0.927 & 0.503 & 0.320 & -0.372 \\
\hline & $(5.02)^{* *}$ & $(0.85)$ & $(4.57)^{* *}$ & $(0.89)$ & $(2.41)^{*}$ & $(0.87)$ & $(0.26)$ & $(0.39)$ \\
\hline \multirow{2}{*}{$\begin{array}{l}\text { Largest ethnic group } \\
\text { in kec has pop share } \\
\text { less } 40 \% \mathrm{CE}\end{array}$} & 0.302 & 0.363 & 0.314 & 0.078 & 0.437 & 0.411 & & -0.326 \\
\hline & $(1.90)$ & $(1.75)$ & $(2.09)^{*}$ & $(0.32)$ & $(2.15)^{*}$ & $(1.97)^{*}$ & & $(0.64)$ \\
\hline \multirow{3}{*}{$\begin{array}{l}\text { Horizontal inequality: } \\
\text { (Max/Min Group HH } \\
\text { Head Education in } \\
\text { Kecamatan) CE }\end{array}$} & -0.004 & -0.005 & -0.006 & -0.005 & -0.002 & -0.004 & 0.004 & -0.008 \\
\hline & & & & & & & & \\
\hline & $(2.43)^{*}$ & $(1.61)$ & $(3.17)^{* *}$ & $(1.37)$ & $(0.99)$ & $(1.29)$ & $(0.54)$ & $(0.76)$ \\
\hline \multirow{2}{*}{$\begin{array}{l}\text { There are marriages } \\
\text { across ethnicity in this } \\
\text { village PO }\end{array}$} & 0.253 & 0.269 & 0.268 & 0.411 & 0.127 & 0.229 & 0.783 & 0.536 \\
\hline & $(3.34)^{* *}$ & $(1.52)$ & $(3.43)^{* *}$ & $(2.35)^{*}$ & (1.63) & $(1.33)$ & $(4.21)^{* *}$ & $(1.86)$ \\
\hline \multirow{2}{*}{$\begin{array}{l}\text { There is no BPD - } \\
\text { elected village council } \\
\text { - in the village PO }\end{array}$} & -0.080 & & -0.242 & & 0.189 & & 0.536 & -1.711 \\
\hline & $(0.71)$ & & $(2.18)^{*}$ & & (1.13) & & (1.62) & $(1.64)$ \\
\hline \multirow{2}{*}{$\begin{array}{l}\text { Village leader is } \\
\text { female PO }\end{array}$} & -0.364 & 0.010 & -0.339 & 0.142 & -0.346 & 0.028 & -0.958 & -0.824 \\
\hline & $(2.24)^{*}$ & $(0.05)$ & $(2.14)^{*}$ & $(0.68)$ & $(2.17)^{*}$ & $(0.13)$ & (1.59) & $(0.68)$ \\
\hline \multirow{2}{*}{$\begin{array}{l}\text { There are religious } \\
\text { groups in the village } \\
\text { PO }\end{array}$} & 0.243 & 0.274 & 0.242 & 0.352 & 0.248 & 0.290 & 0.232 & 0.483 \\
\hline & $(2.82)^{* *}$ & $(1.85)$ & $(2.79)^{* *}$ & $(2.38) *$ & $(2.85)^{* *}$ & $(1.96)^{*}$ & (1.09) & $(1.64)$ \\
\hline \multirow{2}{*}{$\begin{array}{l}\text { There are traditional } \\
\text { (adat) institutions in } \\
\text { the village PO }\end{array}$} & 0.234 & 0.248 & 0.295 & 0.295 & 0.294 & 0.168 & 0.434 & 0.560 \\
\hline & $(3.08)^{* *}$ & $(1.92)$ & $(4.21)^{* *}$ & $(2.56)^{*}$ & $(2.93)^{* *}$ & $(1.32)$ & $(1.99) *$ & (1.94) \\
\hline \multirow{2}{*}{$\begin{array}{l}\text { Community security } \\
\text { organization exists in } \\
\text { village PO }\end{array}$} & -0.217 & -0.027 & -0.119 & -0.321 & -0.341 & -0.198 & -0.643 & -0.188 \\
\hline & $(2.26)^{*}$ & $(0.13)$ & (1.14) & (1.10) & $(2.09)^{*}$ & (0.99) & $(1.42)$ & $(0.86)$ \\
\hline
\end{tabular}


Table 8: Estimation Results (cont)

\begin{tabular}{|c|c|c|c|c|c|c|c|c|}
\hline $\begin{array}{l}\text { Distance to nearest } \\
\text { police post PO }\end{array}$ & $\begin{array}{l}-0.008 \\
(2.99)^{* *}\end{array}$ & $\begin{array}{l}-0.007 \\
(0.95)\end{array}$ & $\begin{array}{l}-0.006 \\
(2.05)^{*}\end{array}$ & $\begin{array}{l}-0.003 \\
(0.47)\end{array}$ & $\begin{array}{c}-0.008 \\
(2.90)^{* *}\end{array}$ & $\begin{array}{l}-0.009 \\
(1.21)\end{array}$ & $\begin{array}{l}-0.005 \\
(0.49)\end{array}$ & $\begin{array}{l}-0.028 \\
(2.06)^{*}\end{array}$ \\
\hline $\begin{array}{l}\text { Village/Neighborhood } \\
\text { Population (Logged) } \\
\text { PO }\end{array}$ & 0.422 & 0.290 & 0.445 & 0.108 & 0.330 & 0.252 & 0.564 & \\
\hline Constant & $\begin{array}{c}-9.087 \\
(11.96)^{* *}\end{array}$ & $\begin{array}{c}-5.176 \\
(3.98)^{* *}\end{array}$ & $\begin{array}{c}-7.691 \\
(11.86)^{* *}\end{array}$ & $\begin{array}{c}-3.285 \\
(2.66)^{* *}\end{array}$ & $\begin{array}{c}-7.280 \\
(8.74)^{* *}\end{array}$ & $\begin{array}{c}-3.857 \\
(2.93)^{* *}\end{array}$ & $\begin{array}{c}-6.519 \\
(2.96)^{* *}\end{array}$ & $\begin{array}{l}-3.393 \\
(2.12)^{*}\end{array}$ \\
\hline $\begin{array}{l}\text { Observations } \\
\text { Pseudo R2 } \\
\text { Robust z statistics in } \\
\text { parentheses } \\
* \text { significant at } 5 \% ; \\
* * \text { significant at } 1 \%\end{array}$ & $\begin{array}{l}53435 \\
0.0801\end{array}$ & $\begin{array}{c}6454 \\
0.1009\end{array}$ & $\begin{array}{l}53435 \\
0.0543\end{array}$ & $\begin{array}{c}6454 \\
0.0483\end{array}$ & $\begin{array}{l}56695 \\
0.1362\end{array}$ & $\begin{array}{c}6549 \\
0.0971\end{array}$ & $\begin{array}{l}7527 \\
0.0590\end{array}$ & $\begin{array}{c}2140 \\
0.0916\end{array}$ \\
\hline
\end{tabular}

Robust $z$ statistics in parentheses

* significant at $5 \%$; ** significant at $1 \%$ 
Figure 1: District Incidence of Conflict

(\% Total Communities Reporting by District (Kabupaten/Kota)

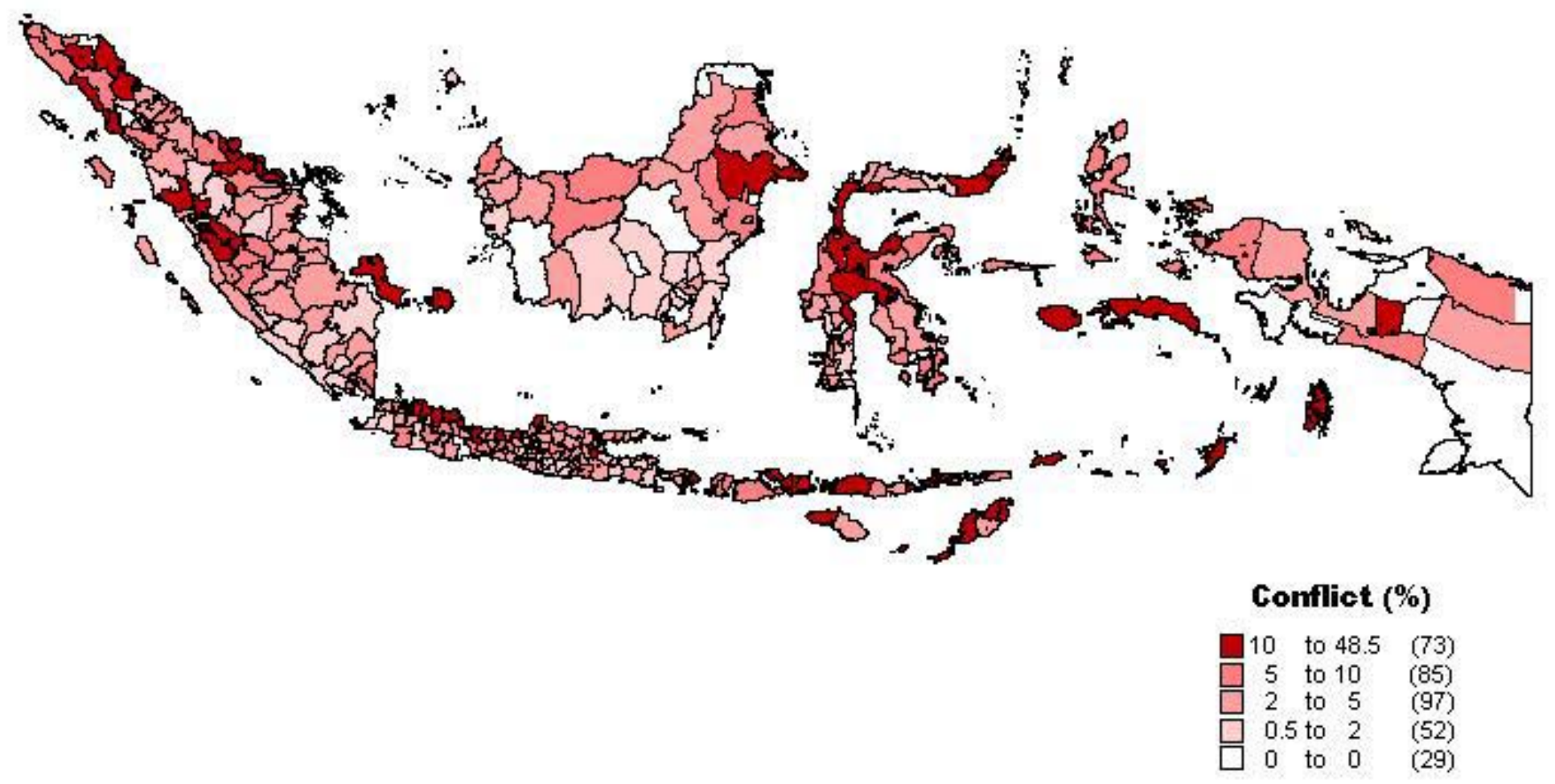

Source : Podes 2003 